\title{
Halophytic bacterial endophytome: a potential source of beneficial microbes
} \section{for a sustainable agriculture}

\author{
Christos A. Christakis', Georgia Daskalogiannis², Anastasia Chatzakis ${ }^{3}$,Emmanouil A.
} Markakis ${ }^{3}$, Angeliki Sagia ${ }^{2}$, Giulio Flavio Rizzo ${ }^{4}$, Vittoria Catara4, Ilias Lagkouvardos ${ }^{5}$, David J. Studholme ${ }^{6}$, Panagiotis F. Sarris ${ }^{1,2,6^{*}}$

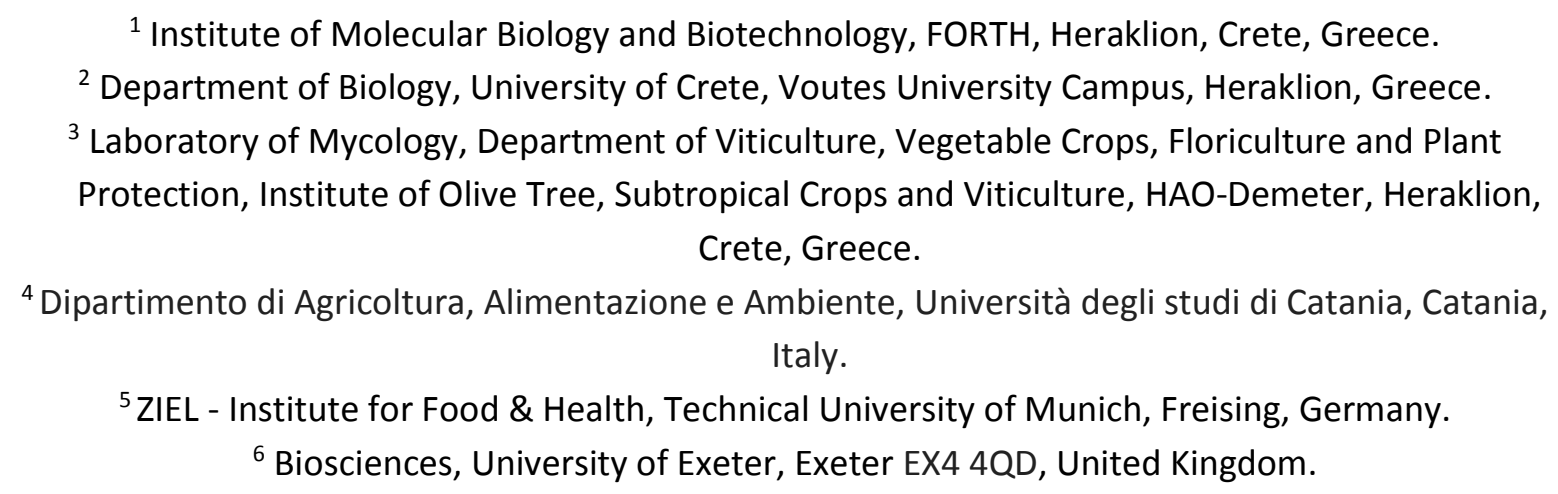
Italy.

${ }^{5}$ ZIEL - Institute for Food \& Health, Technical University of Munich, Freising, Germany. ${ }^{6}$ Biosciences, University of Exeter, Exeter EX4 4QD, United Kingdom.

*Corresponding Author: p.sarris@imbb.forth.gr; p.sarris2@exeter.ac.uk

\section{Abstract}

Halophytes have evolved several strategies to survive in saline environments; however, additional support from their associated microbiota could help combat adverse conditions. Endophytic communities of halophytes may be different than those in other plants because salinity acts as an environmental filter. At the same time, they may contribute to the host's adaptation to adverse environmental conditions and can improve host tolerance against various biotic and abiotic stresses, which may be of importance in modern and sustainable agriculture.

In this study the culturable endophytic bacteria of three halophytic species Cakile maritima, Matthiola tricuspidata and Crithmum maritimum were isolated and identified. Endophytic bacteria were isolated from roots and leaves of the sampled plants. Significant differences were observed in bacterial species abundance among different plant species and tissue from which the isolates were obtained. In total, 115 strains were identified by analysis of complete $16 \mathrm{~S}$ rDNA sequences, while the majority of these isolates were derived from the root samples.

The strains were evaluated for their ability to: 1) grow in-vitro in high levels of $\mathrm{NaCl} ; 2$ ) inhibit the growth of the economically important plant pathogenic fungus Verticillium dahliae in vitro and in planta, the human pathogenic fungus Aspergillus fumigatus in vitro, as well as, the economically important plant bacterial pathogens Ralstonia solanacearum and Clavibacter michiganensis in vitro; 3) provide salt tolerance in planta; 4) provide growth promoting effect in planta.

Additionally, the genomes of twelve selected isolates, exhibiting interesting features, were sequenced and analysed. Three novel bacterial species were identified that belong to the genus Pseudomonas (two strains) and Arthrobacter (one strain). 
Christakis et. al., Halophytic Endophytes in sustainable agriculture

43 The outcome of our study is the proof-of-concept that the crop wild relatives (CWR) 44 halophytic microbiome could potentially serve as a source of beneficial microorganisms that 45 could be used (as unique species or as artificial communities) as Bio-Inoculants, for the 46 enhancement of plant growth and stress tolerance in crops, including the high-salinity stress. 47 This is very important in the era of ecosystem degradation and climate change, where 48 the maximizing microbial functions in agroecosystems could be a prerequisite for the future 49 of global sustainable agriculture. Globally, there is a strong need for the identification and 50 bio-banking of novel beneficial endophytic microbes with as many desirable characters, for 51 the development of a new environmentally friendly global strategy in food production that 52 will be based in the sustainable agriculture with low chemical inputs and a low environmental 53 impact. 
Christakis et. al., Halophytic Endophytes in sustainable agriculture

\section{Introduction}

Bacterial endophytes are endosymbiotic microorganisms widespread among plants that colonize intercellular and intracellular spaces of all plant compartments. Each individual plant is a host to bacterial and fungal endophytes that colonize plant tissues for all or part of the life cycle of their host plant without causing any apparent pathogenesis [1]. Plant-microbe interaction studies have shown the contribution of microbial communities to the defence mechanisms of plants, as well as the substantial beneficial effects they can have on their host plant including improved acquisition of nutrients, accelerated growth, resilience against pathogens, and improved resistance against abiotic stress conditions such as heat, drought, and salinity [2].

The diversity and the structure of endophytic microbiome are dynamic and directly affected by ecological characteristics of the plant and soil such as the plant's geographic location, the environmental factors and interactions within the host plant [3]. Specific members of the endophytic microbiome are part of a core microbiome [4] and most characterized members of endophytic microbial communities belong to the Actinobacteria, Bacteroidetes, Firmicutes, and Proteobacteria phyla $[3,5,6]$; however, endophytic microbiome structure can be affected by the host plant species, genotype (e.g. innate immunity receptors), plant organ or tissue type, developmental stage, growing season, geographic and field conditions, soil type, nutrient status of the host species and cultivation practices $[2,7,8]$.

Endophytic microbes hold an enormous potential to increase host health. Endophytic bacteria can be used to overcome the effect of salinity stress, promote plant growth and to increase plant biomass and nutrient uptake; these approaches can provide a beneficial and environmentally friendly solutions for a sustainable global food security [9-11]. For successful 
Christakis et. al., Halophytic Endophytes in sustainable agriculture

use of endophytes, we need a deeper understanding of the endophytic community composition and the mechanisms that underlie the plant growth promotion, in order to successfully select the most efficient bacterial strains. Selected bacterial strains can be used in various combinations as synthetic communities in top-down approach to affect and study the endophytic microbiome.

Within endophytic bacterial communities, members show a strong influence on each other, which could include antagonistic, competitive, and mutualistic interactions [4]. This is the result of the nutritional competition, exchange, and even interdependence where metabolite exchange among microbes facilitates growth of some microbial species and in turn can influence microbiome composition of a given host species and their effect on the host, and therefore determine the final effect of plant microbiota-interactions in given conditions [2]. This is important when introducing new species or communities into an agricultural field or when trying to isolate the causative beneficial species in complex microbiomes. The host "genotype" can also have a dramatic impact on individual microbial species; individual cultivars can influence the structure of microbial communities and even the beneficial effects of endophytic bacteria $[2,12-14]$. Thus, for the utilization of endophytic bacterial strains, an optimum approach is to isolate key bacterial strains from wild crop relatives (WCRs) [15]. Halophytes could be valuable potential sources of novel endophytic strains that can be used to overcome salinity stress, overcome plant diseases and augment plant growth [1619]. Since, soil salinity not only disrupts the physiological and morphological plant processes but also increases susceptibility to pathogens - a major hindrance to crop yields [19] - the use of plant growth-promoting endophytes, isolated from halophyte WCRs for use in crops, can be a more eco-friendly approach than the use of agricultural chemicals. 
Christakis et. al., Halophytic Endophytes in sustainable agriculture In the present study, we test the hypothesis that the cultivated endophytic bacteria

103 isolated from three halophytic plant species, two of Brassicaceae family (or Cruciferae):

104 Matthiola tricuspidata and Cakile maritima, and one of Apiaceae family: Crithmum 105 maritimum, have properties of salinity stress tolerance, plant growth promotion and 106 phytopathogen growth inhibition and could have a predominant role in the future for a 107 sustainable crop production of crops belonging mainly but not exclusively to those two plant 108 families. In order to test this hypothesis, we isolated, cultured and identified 115 different bacterial strains and functionally characterized them using in-vitro and in-planta assays. This

110 is the first study of bacterial endophytes obtained from Matthiola tricuspidata, Crithmum maritimum and Cakile maritima, which identifies their potential use as bacterial inoculants in

112 commercial plants in order to overcome salinity stress and important plant diseases caused

113 by the economically important pathogens Verticillium dahliae, Ralstonia solanacearum and 114 Clavibacter michiganensis ssp. michiganensis. 
Christakis et. al., Halophytic Endophytes in sustainable agriculture

Material and Methods

\section{Site description and plant sample collection}

Figure S1). At S1, a natural beach area that favours salt-marsh vegetation, three Matthiola

Each sample was collected with sterile tools, placed in separate plastic bags to avoid cross contamination and immediately transported to the laboratory for processing.

\section{Plant surface sterilization endophytic cell isolation}

140 efficiency by plating on NA medium and monitored for microbial growth. Approximately

142 for further processing. Only successfully sterilized root material was used for further analysis. 
Christakis et. al., Halophytic Endophytes in sustainable agriculture

From each sample 0.5 - $1 \mathrm{gr}$ of fresh biomass was cut into smaller pieces using a sterile scalpel and further grounded into a slurry with an autoclaved pestle and mortar. The slurry was

145 transferred into sterile petri dishes and $30 \mathrm{ml}$ of autoclaved $\mathrm{dH}_{2} \mathrm{O}$ was added. The petri dishes

147 of the material in triplicate were plated on Nutrient Agar (NA) plates using spread plate

148 technique. Plates were incubated at $28^{\circ} \mathrm{C}$. Unique bacteria from each plate were chosen

149 based on colony colour and morphology. Pure bacterial colonies were grown in Nutrient Broth

150 (NB) and cells stocks were stored in $50 \% \mathrm{v} / \mathrm{v}$ glycerol at $-80^{\circ} \mathrm{C}$. A total of 115 strains were

151 isolated.

152

\section{Bacterial isolation and strains identification}

A total of 115 bacterial isolates were isolated from the various plant tissue samples,

based on morphological criteria of their forming colonies and their identities confirmed by the $16 \mathrm{~S}$ rDNA sanger sequencing method.

To extract crude genomic DNA $1 \mathrm{ml}$ of liquid bacterial culture in NB medium, was placed in liquid nitrogen for $15 \mathrm{sec}$. After incubation in room temperature, the lysate was centrifuged at $10,000 \times \mathrm{g}$ for $1 \mathrm{~min}$. Two $\mu \mathrm{l}$ of the lysate were used to amplify the $16 \mathrm{~S}$ rDNA genes using primers 27F: 5'-AGAGTTTGATCCTGGCTCAG-3' [20] and 1492R: 5'-GTTTACCTTGTTACGACTT-3'

162 Thermocycler with initial denaturation at $94{ }^{\circ} \mathrm{C}$ for $2 \mathrm{~min}$, followed by 35 cycles of 5 sec at 94

164 for 5 min. Apart from the lysate, each tube contained, Bac-Free PCR Buffer, $250 \mathrm{nM}$ of each primer, $0.2 \mathrm{mM}$ of each deoxy- ribonucleotide triphosphate and 0.1 U BAC-Free HotStart Taq 
Christakis et. al., Halophytic Endophytes in sustainable agriculture

167

168

169

170

171

172

173

174

175

176

177

178

179

180

181

182

183

184

185

and PCR Clean up (Macherey-Nagel, Germany). The cleaned-up PCR products were sent Macrogen (Europe) for sequencing with primer $27 \mathrm{~F}$.

The resulting chromatograms were quality inspected using MEGA5 [22] and the start/end regions of low quality were manually trimmed off. Cleaned-up fasta files were aligned in SILVA [23]. The resulting nearly complete sequences of the $16 \mathrm{~S}$ rDNA gene were queried against ezBioCloud [24] reference database for identification and documentation of the described bacterial strain with the closest sequence similarity.

\section{Bacterial salt tolerance assay}

The salt tolerance of all bacterial isolates was estimated on the basis of the population density of these strains at different concentrations of $\mathrm{NaCl}$ [(ranging from $0.5 \% 5 \%, 10 \%, 15 \%$ and $17,5 \%(\mathrm{w} / \mathrm{v})]$ in NA medium. Sterilized petri plates containing $25 \mathrm{~mL}$ NA medium with increasing $\mathrm{NaCl}$ concentrations were inoculated with $10 \mu \mathrm{l}$ drops of freshly prepared NB of all strains and incubated at $28^{\circ} \mathrm{C}$. For each $\mathrm{NaCl}$ concentration, an Escherichia coli laboratory strain was inoculated as a negative control. After $24 \mathrm{~h}$ of incubation, the growth of the culture was estimated compared to E. coli growth.

\section{In-vitro growth inhibition of phytopathogens}

Antibacterial activity of the bacterial isolates against the phytopathogenic bacteria Ralstonia solanacearum and Clavibacter michiganensis was evaluated by co-culturing each of the 115 bacterial isolates on NA plate lawn covered by $R$. solanacearum or $C$. michiganensis. The inhibition zone indicating bacterial growth inhibition was recorded as the antibacterial effect. Antifungal activity of the isolates against Verticillium dahliae was investigated. PDA medium was incubated with each bacterial isolate for $24 \mathrm{~h}$ at $28^{\circ} \mathrm{C}$ and then $\mathrm{V}$. dahliae was 
Christakis et. al., Halophytic Endophytes in sustainable agriculture inoculated at room temperature for 3-4 weeks. Fungal growth inhibition was determined by measuring the inhibition zone of $V$. dahliae hyphae on the media.

\section{In-vitro hemolysis screening assay} at room temperature for $48 \mathrm{hrs}$. The known non-mammalian-pathogenic species Ensifer meliloti was employed as a negative control.

In-vitro growth inhibition of fungal human pathogen

Antifungal activity of specific isolates against anthropopathogenic fungus Aspergillus

fumigatus was evaluated by co-culturing 11 bacterial isolates on NA plate lawn covered by $A$. were tested: CML04, CMR11, CMR22, CMR25, CrR12, CrR25, MTR12, MTR17a, MTR17b, the $A$. fumigatus hyphae on the media. in high salinity conditions (up to $17.5 \% \mathrm{w} / \mathrm{v} \mathrm{NaCl}$ ), in order to test their capacity to promote plant growth of the model plant Arabidopsis thaliana. Firstly, the experiment was performed

214 with no abiotic stress conditions. The bacterial strains were cultured in Nutrient Broth 
Christakis et. al., Halophytic Endophytes in sustainable agriculture

medium for $46 \mathrm{~h}$ at $25^{\circ} \mathrm{C}$ with stirring. The liquid cultures were centrifuged at $224 \times \mathrm{g}$ for 15

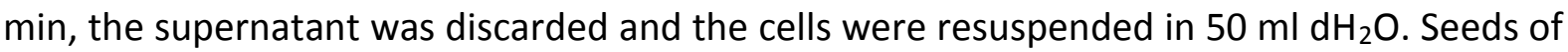

217 Arabidopsis thaliana ecotype Columbia (Col-0) were grown in plastic pots $(6 \times 6 \times 7 \mathrm{~cm})$ filled with vermiculite: soil (1:1), at $25^{\circ} \mathrm{C}(16 \mathrm{~h}$ light / $8 \mathrm{~h}$ dark). For each bacterial strain and the corresponding control, 5 individual plants were grown in each pot. $A$. thaliana plants were watered with $\mathrm{dH}_{2} \mathrm{O}$ for 10 days. Then, plants were watered with $10 \mathrm{ml}$ suspensions of the 12 re-dissolved bacterial strains for 7 days in order to let the bacterial strains to adapt. Following

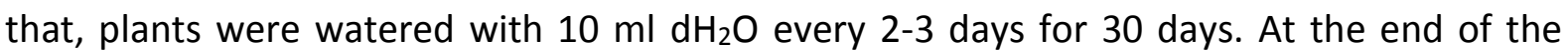
treatment, the fresh weight of the leaves of each plant was measured. The leaves were then dried at $65-70{ }^{\circ} \mathrm{C}$ for 2 days and their dry weight was measured.

The same experiment was performed under salt treatment. Specifically, after the 7-day period of bacterial strain inoculation, instead of $\mathrm{dH}_{2} \mathrm{O}$, the plants were watered with $10 \mathrm{ml}$ of 200-250 mM NaCl. Fresh and dry weight of the leaves as measured.

For both experiments, mock samples were employed were no bacterial strains were

inoculated and control plants that were inoculated with the strain Escherichia coli (Control-E. coli). The last control was used to check that the plants would not use the bacteria as a fertilizer.

\section{Confrontation and volatile tests of selected bacterial strains against $V$. dahliae}

Direct in vitro antagonism of $V$. dahliae by selected bacterial strains was evaluated by

In particular, a 6-mm diameter mycelial disc taken from the periphery of a 2-week-old PDA 
Christakis et. al., Halophytic Endophytes in sustainable agriculture strain (taken from a 48-h-old TSB liquid culture with an inoculation loop) was streaked on the opposite site of the plate at equal distance from the center (one strain per plate). Moreover,

Trichoderma harzianum strain T22 was isolated from the commercial biofungicide TRIANUMonly with $V$. dahliae agar discs were served as controls. Plates (three per bacterial strain plus controls) were incubated at $24{ }^{\circ} \mathrm{C}$ in the dark. The radius of fungal colonies towards the direction of the test strain and that of controls was measured 5, 7, 9 and 12 days post inoculation (d.p.i.) and radial growth rates were expressed in $\mathrm{mm} /$ day. At the end of the bioassays (12 d.p.i.) the underside of the plates was scanned using a Samsung Xpress SLM2875ND Laser Multifunction Printer at 1200 dpi and microsclerotial area on each plate image was determined manually using the image processing software Image $1.46 r$ (National Institutes of Health, USA). Then, the number of spores was estimated by transferring a 6-mmdiameter disc taken from the periphery of each culture into a $1.5 \mathrm{ml}$ Eppendorf tube with 1 $\mathrm{ml}$ of water, and vortexed for 30 seconds. The number of spores was measured with the use of a haematocytometer under a light microscope. Moreover, actively growing mycelia from cultures' periphery (located closer to test strain) were prepared and microscopic observations (30 readings per culture) were carried out to estimate hyphae width.

To evaluate the capacity of bacterial strains to affect $V$. dahliae growth via the production of volatile compounds, dual-plate assays [25] were conducted (volatile test). In brief, one 6-mm-diameter agar disc of actively growing mycelium of the fungus was placed in the center of a new PDA plate (90 $\mathrm{mm}$ in diameter), whilst each bacterial strain (taken from a 48-h-old TSB liquid culture) was streaked on another PDA plate. Then, the covers of the two plates were removed and resultant plates were adjusted together (bacterial culture was 
Christakis et. al., Halophytic Endophytes in sustainable agriculture headspace without coming in contact with each other. Dual plates (upright and upturned) inoculated only with $V$. dahliae were served as controls. Likewise, in dual-culture assays, dualplates (three per bacterial strain) were incubated at $24{ }^{\circ} \mathrm{C}$ in the dark and the radial growth, microclerotial area, sporulation and hyphae width of fungal colonies was measured as described above. inhibition ( $\mathrm{SI}$ ) and hyphae thinning $(\mathrm{HT})$ were calculated according to the formula: ((Vc$\mathrm{Vt}) / \mathrm{Vc}) \times 100$ where $\mathrm{Vc}=$ the microscopic value of $\mathrm{V}$. dahliae in control plates and $\mathrm{Vt}=$ the respective value of $V$. dahliae against the antagonistic strain in dual-culture or dual-plate assays.

Bacterial strains and fungal inoculum preparation for in-planta bioassays

Fifteen bacterial strains (assigned as CrR14, CrR18, CrR04, MTR12, MTR18, CMR01,

CMR03, CML04, CMR25, MTR17a, MTR17d, MTR17f, MTR17g, MTR17h and MTR17b, (TSB) liquid culture in Erlenmeyer flasks of $500 \mathrm{ml}$ capacity, containing $200 \mathrm{ml}$ of the medium, in an orbital incubator at $180 \mathrm{rpm}$ and $28^{\circ} \mathrm{C}$ for $48 \mathrm{~h}$ in the dark. Bacterial suspensions were centrifuged at $3000 \times \mathrm{g}$ for $10 \mathrm{~min}$ and cells were re-suspended in water reaching a final concentration of $10^{8} \mathrm{cfu} \mathrm{ml}^{-1}$ (measured by dilution plating).

The highly virulent $V$. dahliae isolate 999-1 [26], which originated from a symptomatic eggplant (Solanum melongena L.), was used. Verticillium dahliae conidial suspension for eggplant-V. dahliae bioassays was prepared according to Markakis et al. (2016). In brief, conidia were produced by growing each $V$. dahliae strain in potato dextrose broth (PDB) at 
Christakis et. al., Halophytic Endophytes in sustainable agriculture

three layers of cheesecloth and the suspensions centrifuged at $3000 \times \mathrm{g}$ for $10 \mathrm{~min}$. Spores were re-suspended in sterilized distilled water and their concentration was adjusted to $5 \times$ $10^{6}$ conidia $\mathrm{ml}^{-1}$.

\section{In planta verticillium wilt suppression bioassays}

one-true-leaf stage, grown in 100 ml-capacity pots containing soil substrate (HuminSubstrat, of $10^{8} \mathrm{cfu} \mathrm{ml}^{-1}$ of each strain per plant), whereas plants that served as controls (negative=no bacterium/no fungus assigned as ' $C-$ ' and positive=no bacterium/plus fungus assigned as conidial suspension ( $20 \mathrm{ml}$ of $5 \times 10^{6}$ conidia $\mathrm{ml}^{-1}$ per pot). Plants that served as negative controls (C-) were treated with $20 \mathrm{ml}$ of water. Eggplants were maintained under controlled conditions at $23 \pm 2{ }^{\circ} \mathrm{C}$ with a 12 -h light and dark cycle. eleven treatments (C-, V.d., V.d.+CrR14, V.d.+CrR18, V.d.+CrR04, V.d.+MTR12, V.d.+MTR18,

experiment II, ten treatments were conducted (C-, V.d., V.d.+MTR17a, V.d.+MTR17d, 
Christakis et. al., Halophytic Endophytes in sustainable agriculture

$P$ was served as a $V$. dahliae-suppressive reference treatment in the present study. Within each experiment, each treatment consisted of seven plants and the experiments were replicated three times ( 21 plants per treatment in total).

\section{Disease assessment}

31712 to 30 days post inoculation with V. dahliae (d.p.i.). Bioassays were evaluated by estimating disease severity, disease incidence, mortality and relative area under disease progress curve (RAUDPC). Disease parameters were recorded according to Markakis et al. [56]. In brief, disease severity at each observation was calculated from the number of wilting leaves, as a percentage of total number of leaves of each plant. Disease ratings were plotted over time to generate disease progress curves. Subsequently the area under disease progress curve (AUDPC) was calculated by the trapezoidal integration method [27]. Disease was expressed as a percentage of the maximum possible area with reference to the maximum value potential reached over the whole period of each experiment and is referred to as relative AUDPC (RAUDPC). Disease incidence was estimated as the percentage of infected plants. Only plants with a final disease severity of $\geq 20 \%$ were considered infected, in order to discriminate between $V$. dahliae-associated disease symptoms and other weak symptoms occasionally observed (Supplementary Table S2). Mortality was estimated as the percentage of dead plants.

\section{Plant growth}

Growth parameters were evaluated at the end of bioassays (at 24 and 30 d.p.i. for 
Christakis et. al., Halophytic Endophytes in sustainable agriculture

335

336

337

338

340

341

342

343

344

345

346

347

348

349

350

351

352

353

354

355

356

357

358

on plant growth, all plants were clipped off at the soil surface level and their height, fresh weight and number of leaves were measured.

\section{Fungal pathogen re-isolation}

To verify the presence of the applied $V$. dahliae strain in plant tissues, five plants per treatment in each experiment were randomly selected. Specifically, the leaves of eggplants which had been cut above the soil level previously were removed and their stems were surface-disinfected by spraying with $95 \%$ ethyl alcohol and by quickly passing them through flame three times. For each plant, 3 xylem chips taken from different sites along the stem (base, middle and upper part of the stem) were aseptically placed onto acidified potato dextrose agar (PDA) after the removal of the phloem. Plates were then incubated at $24{ }^{\circ} \mathrm{C}$ in the dark for 14 days. The emerging fungi that grew out of tissue excisions were examined visually and under a light microscope and identified according to their morphological characteristics [28]. Pathogen isolation ratio was expressed as the frequency of positive $V$. dahliae isolations of each plant.

\section{Statistics}

Analysis of variance (ANOVA) was employed to determine the effects of replication (1, 2 or 3), treatment (C-, V.d., V.d.+CrR14, V.d.+CrR18, V.d.+CrR04, V.d.+MTR12, V.d.+MTR18, V.d.+CMR01, V.d.+CMR03, V.d.+CML04, V.d.+CMR25 in Experiment I and C-, V.d., V.d.+MTR17a, V.d.+MTR17d, V.d.+BMTR17f, V.d.+MTR17g, V.d.+MTR17h, V.d.+MTR17b, V.d.+MTR17c, V.d.+TRIANUM-P in experiment II) and their interaction on disease incidence (DI), final disease severity (FDS), mortality (M), relative area under disease progress curve (RAUDPC) and isolation ratio (IR), and on plant height, fresh weight and total number of leaves 
Christakis et. al., Halophytic Endophytes in sustainable agriculture

(Supplementary Tables S2 \& S3). Prior to ANOVA, homogeneity of variance across treatments

was evaluated and an arcsine transformation was applied to normalize variance. When a significant $F$ test was obtained for treatments $(P \leq 0.05)$, the data were subjected to means separation by Tukey's honestly significant difference test. Morphological and physiological characteristics of $V$. dahliae in dual-culture and dual-plate assays were also analysed by Tukey's test $(P \leq 0.05)$. Moreover, standard errors of means were calculated.

\section{Bacterial total genome sequencing}

Genome sequences of twelve bacterial isolates were determined using a 250 bp pairedend library with the Illumina MiSeq sequencing system (University of Exeter Sequencing sequence annotated using the NCBI Prokaryotic Genome Annotation Pipeline (PGAP). Raw sequence reads and assembled genomes were uploaded to the Sequence Read Archive [30] and GenBank [31] and are available under BioProject accession number PRJNA634334.

Bacterial genome analysis and annotation reliable genome annotation. 
bioRxiv preprint doi: https://doi.org/10.1101/2020.07.29.226860; this version posted July 29, 2020. The copyright holder for this preprint (which was not certified by peer review) is the author/funder. All rights reserved. No reuse allowed without permission.

Christakis et. al., Halophytic Endophytes in sustainable agriculture

383 The phylogenetic-trees were constructed assuming the bootstrap value derived from 1,500

384 replicates to represent the evolutionary history of the included taxa. For the construction of

385 the phylogenetic trees we used the concatenated $\operatorname{rec} A$ and gyrB genes. 
Christakis et. al., Halophytic Endophytes in sustainable agriculture

Results

\section{Isolation and grouping of culturable bacteria}

After surface sterilization, no epiphytic bacteria could be cultivated from the surface of

the roots and leaves of halophytic plants. Endophytic bacteria were cultivated from all three

halophytes and in total, 115 pure cultures showing different colony morphology per isolation

source (plant, root or leaf) were obtained; 91 were retrieved from roots and 24 from leaves.

From M. tricuspidata 45 strains were isolated, from C. maritima 31 strains, and from $C$.

For the 115 isolates, the sequencing of 16S rRNA gene amplicons, yielded sequences of

sufficient length for taxonomic analysis (Figure 1, Supplementary Table S1). The distribution

(Figure 1, Supplementary Table S1). The most prevalent genus among the isolated bacteria

Pseudomonas strains were only isolated from root samples.

407

\section{Shared and unique endophyte taxa among plants and plant compartments}


Christakis et. al., Halophytic Endophytes in sustainable agriculture

411 Table S1). Specifically, the second-most abundantly isolated genus, Enterobacter, was

412 isolated only from root samples (Supplementary Table S1). Similarly, all strains from the

413 genera Enterobacter, Pseudomonas, Microbacterium, Paenarthrobacter, Pantoea,

414 Arthrobacter, Brachybacterium, Arenivirga and Glutamicibacter were isolated from root

415 samples, whereas the strains Oceanobacillus, Planomicrobium and Staphylococcus were

416 isolated only from leaf tissue samples (Supplementary Table S1).

417 The aforementioned most abundant culturable genera were hosted in at least two of 418 the three halophytic species. M. tricuspidata hosted the biggest number of culturable genera

419 (18), whereas C. maritima and C. maritimum hosted 10 and 8 different genera, respectively.

420 C. maritima hosted the biggest number of Enterobacter isolates (13 of the total 22) and the

421 smallest number of Bacillus isolates (2 out 28). Strains in the genera Brachybacterium and

422 Arenivirga were isolated only from M. tricuspidata plants, whilst the Glutamicibacter isolates

423 were hosted only in C. maritimum and the Planomicrobium isolates in C. maritima.

\section{Functional characteristics of isolates}

Bacterial features known to contribute to stress tolerance or biocontrol were tested for

427 their ability to grow in increasing salinity levels (5\%, 7.5\%, 10\%, 15\%, 17.5\%) and their 428 phytopathogen antagonistic activity against known phytopathogenic bacteria and fungi. The results are summarized in Supplementary Table S1. the ability to inhibit the growth of the phytopathogenic fungi Verticillium dahliae, the ability

432 to grow at $7.5 \%$ and $10 \%$ salinity, the ability to inhibit the phytopathogenic bacterium 
Christakis et. al., Halophytic Endophytes in sustainable agriculture threshold and 3 could grow in $10 \%$ salt.

Another 3 additional Bacilli strains (CrR16: Bacillus haikouensis, CrR22: Bacillus haikouensis, MTR05: Terribacillus saccharophilus) that could grow on $15 \%$ salinity, did not grow on $17,5 \%$ salinity (Supplementary Table S1).

\section{Phytopathogens growth inhibition ability}

All 115 bacterial strains were subjected to in vitro inhibition assays against 3 known phytopathogens: the bacteria Ralstonia solanacearum and Clavibacter michiganensis subsp. 
Christakis et. al., Halophytic Endophytes in sustainable agriculture

459

460

461

462

463

464

465

466

467

468

469

470

471

472

473

474

475

476

477

478

479

480

481

bacteria, the bacterial isolates that showed any kind of inhibition were characterized as having "weak", "medium" or "strong" inhibitory activity based on the size of the inhibition zone around the bacterial colony (Figure 2). In the in-vitro assay against Verticillium dahliae the inhibitory activity was similarly judged as "weak", "medium" or "strong" based on the linear distance between the bacterial and the fungal colonies (Figure 2).

Only 25 (21.7\%) of the 115 bacterial strains demonstrated an inhibition zone of the Ralstonia solanacearum growth (Supplementary Table S1). These 25 strains belong to six genera: Bacillus, Enterobacter, Erwinia, Glutamicibacter, Paenarthrobacter and Pseudomonas. Only one strain isolated from leaf tissues of the 3 halophytes showed any kind of inhibitory activity; Bacillus altitudinis (strain CMLO4) isolated from C. maritima.

Of the 45 strains isolated from M. triscupidata plants, 3 strains showed a weak inhibitory zone against Ralstonia. A total 10 strains (7 from C. maritima and 3 from C. maritimum), that belong to either to the genera Enterobacter and Pseudomonas (Supplementary Table S1), showed a strong inhibition zone (Figure 2).

An even lower number of strains showed any kind of inhibition against the phytopathogenic Clavibacter michiganensis subsp. michiganensis: a total 17 strains out of 115 (14.8\%). All 9 isolates from M. triscupidata, that are Bacillus licheniformis or Bacillus sonorensis strains, demonstrated a strong inhibition zone (Figure 2). Similarly, 2 strains from C. maritimum roots (both Pseudomonas glareae, $\mathrm{CrR} 12$ and $\mathrm{CrR} 13$ ) showed a strong inhibition zone (Supplementary Table S1). An additional 2 and 4 strains showed weak and medium inhibition zone against Clavibacter, respectively (Supplementary Table S1). Interestingly, a large majority (76.5\%) of the bacterial isolates demonstrated some kind of inhibition of the phytopathogenic fungus Verticillium dahliae (Supplementary Table S1). 
Christakis et. al., Halophytic Endophytes in sustainable agriculture

482

483

These strains originate from both leaf and root tissue from all 3 halophytes. A strong inhibition zone was demonstrated by 34 of these 88 strains, all of which except one, were isolated from the roots of halophytic plants (Supplementary Table S1). From these 34, 11 strains belong to the genus Bacillus, another 11 to Pseudomonas, 5 to Enterobacter, 2 to Microbacterium and the rest belong Agrococcus, Arthrobacter, Paenarthrobacter, Sphingobacterium and Sphingopyxis (Supplementary Table S1).

Eleven of the strains were tested for inhibition against the human pathogenic fungus Aspergillus fumigatus. Interestingly, five of these strains were able to inhibit the growth of $A$. fumigatus (Figure 2). The strain CML04 (Bacillus altitudinis) isolated from C. maritima was the only strain isolated from leaf tissues that was able to show inhibitory effect, while all rest strains were isolated from the roots of $M$. triscupidata (Supplementary Table S1). Two strains MTR17d (Bacillus sonorensis) and MTR17b (Bacillus licheniformis) showed a strong zone of inhibition (Figure 2, Supplementary Table S1).

\section{In planta assay for plant growth promotion and salt tolerance}

Bacterial isolates with salt tolerance between $10 \%$ and $17.5 \% \mathrm{NaCl}$ concentration at the in-vitro assays were selected for the in-planta assays regarding their plant growth promotion under "no stress". The model plant species Arabidopsis thaliana (Brassicaceae) was imbued with bacterial cultures for 7 days. After this period where the bacteria were left to adapt, the plants were watered for a month where the fresh and dry weight of the leaves was calculated (Table 1). As negative controls, $\mathrm{dH}_{2} \mathrm{O}$, as well as, E. coli cultures were used.

The same experiment was repeated where after the 7-day mark, the plants were watered with $10 \mathrm{ml}$ of $250 \mathrm{mM} \mathrm{NaCl}$ solution every 2-3 days for 30 days. Except the aforementioned controls, an additional control of salty water was implemented. 
Christakis et. al., Halophytic Endophytes in sustainable agriculture

CrR16, CrR23, MTR05 showed an increase in fresh leaf weight between 1.1 and 2.6 times to the non-inoculated plants and between 1.0 and 2.3 times increase in dry leaf weight (Table 1). leaf weight, respectively (Table 1). no stress and under salt stress whereas strain CrR22 had a positive affect only under salt stress condition (Table 1). On the other hand, strains CML12, CrL01, CrL11, CrR16 and CrR23 had a positive effect on fresh and dry weight under no stress condition (Table 1).

\section{Direct and indirect in-vitro effects on Verticillium dahliae growth} capable of inhibiting fungal sporulation (except of MTR17g) in dual-culture assays. While, some strains caused a significant induction of $V$. dahliae sporulation in such assays (MTR17h, MTR17b and MTR17c) indicating that fungal growth suppression induces fungal sporulation. Moreover, 6 out of 16 strains could reduce significantly hyphae width in direct culture conditions whereas 7 out of 16 were capable of reducing hyphae width by the mean of 
Christakis et. al., Halophytic Endophytes in sustainable agriculture

culture assays; however only 3 strains reduced microsclerotia formation significantly in dualplate assays. Interestingly, MTR17h caused a significant induction in microsclerotia formation either in dual-culture or in dual-plate assays.

\section{Suppression of Verticillium wilt symptoms in-planta}

For the suppression of Verticillium dahliae wilt symptoms in-planta we used a welleffect to Verticillium. disease severity at 18 and 21 d.p.i. whereas MTR18 and CM1 treatments caused significant reduction of disease severity at most observation time points (Table ). Taken all disease parameters into account, CMR01 was the most effective strain in terms of disease

547 experiment II were also observed on 12 d.p.i. and recorded until 30 d.p.i. Disease severity progressed rapidly in the control (V.d.) and the non-suppressive treatments (MTR17d, MTR17f and MTR17g), whereas MTR17a-, MTR17h-, MTR17b- and MTR17c-treated plants

550 showed less prominent symptoms and slower disease development (Table 2; Figure 5). Data

551 on various disease parameters indicated that strain MTR17h, is comparable to the positive control used in these assays, the fungus Trichoderma harzianum strain TRIANUM-P, both 
Christakis et. al., Halophytic Endophytes in sustainable agriculture decrease in symptom severity in MTR17h-treated plants was associated with significantly lower $V$. dahliae re-isolation ratio compared to positive control (V.d.) plants, indicating less active growth of the pathogen into the xylem vessels. The interesting observation here is that the MTR17h isolate does not reveal strong growth inhibition effect on $V$. dahliae in our invitro assays. This result could suggest the plant innate immunity activation/reinforcement effect by the particular bacterial isolate, which needs to be further investigated in the future. Neither symptoms nor positive isolations were observed in negative control plants.

\section{Effects of treatments in plant growth} treated with various bacterial strains and the T. harzianum strain TRIANUM-P or not (C-), are shown on Table 3. Verticillium dahliae-inoculated plants treated with MTR17c and T. harzianum TRIANUM-P developed significantly higher fresh weight compared with the $V$. dahliae-inoculated controls, whereas most of the plant growth parameters in non-inoculated plants were significantly higher than in the inoculated ones.

Whole-Genome sequencing and analysis of selected endophytic bacterial isolates could provide unprecedented resolution in discriminating even highly related lineages of bacteria and revolutionize analysis that could help to understand their futures including 
Christakis et. al., Halophytic Endophytes in sustainable agriculture

578

579

580

581

582

583

584

585

586

587

588

589

590

591

592

593

594

595

596

597

598

599

600

genome annotation tools (Supplementary Figure S2). Furthermore, all the genes related to the virulence, disease and defence that have been predicted at the particular isolates' genomes, were identified (Table 4 and Table S2). These data form the basis for future studies regarding the genome features that contribute to antifungal and antibacterial properties of these bacterial isolates.

Interestingly, our whole-genome sequencing, the specific genes sequence comparison and the average nucleotide identity analysis, revealed the presence of three totally new bacterial species. To further investigate this finding we extracted the $\operatorname{rec} A$ and $g y r B$ gene sequences from the genomes and after concatenation we constructed phylogenetic trees using representatives from the related bacterial groups in order to investigate the phylogeny of our isolates (Figures 6 \& 7). Two of these species belong to Pseudomonas family, while the third is a member of Arthrobacter family. The isolates CMR25 and CMR27 seem to belong to an unidentified species of the $P$. putida group (Figure 7), and the isolate CrR25 appears to be an undefined species of the $P$. mendocina group (Figure 7). Their 16S rDNA sequence of both CMR25 and CMR27 are similar 99.8\% to Pseudomonas plecoglossicida and the 16S rDNA of CrR25 is $98.75 \%$ similar to Pseudomonas benzenivorans. While the genome analysis and annotation the isolate CMR16 belong to an unidentified Athrobacter species (Figure 6), its 16S rDNA sequence assigns the isolate to Paenarthrobacter nitroguajacolicus with $98.78 \%$ similarity.

The identification of three new bacterial species in such a small number of WGS of our isolates, reveals the potentiality that the wild halophytic endophytome has regarding the isolation and the identification of new microbial species with novel capacities, that could be beneficial for both Agriculture (biotic and a-biotic stress tolerance, growth promotion, etc.) 
bioRxiv preprint doi: https://doi.org/10.1101/2020.07.29.226860; this version posted July 29, 2020. The copyright holder for this preprint (which was not certified by peer review) is the author/funder. All rights reserved. No reuse allowed without permission.

Christakis et. al., Halophytic Endophytes in sustainable agriculture

601 and potentially in clinical practice (identification of new antibiotics, antifungal compounds,

602 etc.).

603 
Christakis et. al., Halophytic Endophytes in sustainable agriculture

604

605

606

607

\section{Discussion}

Of the nearly 391,000 species of vascular plants that exist in the earth, each is the host of a number of endophytes. Only a small number of these plants have ever been completely studied in respect to their endophytic composition. On the other hand, the use of endophytic microorganism for the control of both biotic and abiotic stresses, is relatively new and unexplored area of research. Endophytes have been studied for over two decades [35-37], but our understanding about the role of endophytic microbes in plant defense against biotic and abiotic stresses is still limited $[38,39]$. The isolation, identification and the study of endophytes from plants that undergo continued abiotic stress could be essential for the development of proper biocontrol strategy for a sustainable agriculture and food security.

Even if scientific approaches on the diversity of endophytes have recently gained interest in plant-microbe research field, information on endophytes' content and their potential contribution on the mutualistic interactions with cultivated plant species remain unclear. For the future precision in agriculture, targeted application of culturable beneficial microbial "artificial communities" may be a sustainable path to counteract biotic and abiotic stress conditions and ensure yield stability. However, within the endophytic bacterial communities, members show a strong influence on each other, which could include antagonistic, competitive, and mutualistic interactions [2]. This is important when introducing new species or communities into an agricultural field or when trying to isolate the causative beneficial species in complex microbiomes. Among the beneficial traits that are of particular significance, with potential to be exploited in crop ecosystems is the promotion of plant growth, the control of plant diseases and the high salinity tolerance. However, and apart from their use in agriculture, additional applications of endophytes could rely on their ability to 
Christakis et. al., Halophytic Endophytes in sustainable agriculture

627

628

630

631

632

633

634

636

641

642

644

646

647

648

649

650

produce a broad range of bioactive metabolites that are relevant for other purposes, including human health (antibiotics, antitumor compounds, etc.).

In this study, we investigate the abundances of taxa of the culturable bacterial endophytes of three halophytic plants, endemic in Crete Island, Greece, using culturedependent techniques. We also investigate the proof-of-concept of using the halophytes as a valuable source of beneficial microbes that will be used in future agriculture. We tested our initial hypothesis that these endophytes can be used as potential biofertilizers and biocontrol agents for a sustainable agriculture. Taxonomically, all bacterial isolates belong to the phyla Actinobacteria, Firmicutes and Proteobacteria (either the Alphaproteobacteria or Gammaproteobacteria classes). While 24 different genera were identified, the three of the most abundant genera were Bacillus and Enterobacter and Pseudomonas, all of which have been previously observed before in studies of the endophytic microbiome of halophytes [16, $18,40,41]$.

In planta testing of Oceanobacillus picturae (CML15), Terribacillus saccharophilus (MTR05) and Bacillus haikouensis (CrR22) demonstrated an increase in both dry and fresh leaf weight in Arabidopsis thaliana plant under salinity stress. These strains are promising biofertilizers, since other strains of the same species have been shown to have plant growth promotion properties. Terribacillus saccharophilus, firstly reported at 2007, is a known halophilic bacterium that can grow on $\mathrm{NaCl}$ concentrations ranging $0-16 \%[42,43]$. This species is a known endophytic bacterium [44], that has been shown a systemic response that trigger an increase on monoterpenes, sesquiterpenes, tocopherols and membrane sterols, compounds engaged in antioxidant capacity in leaf tissues of grape resulting in stress tolerance [45]. Bacillus haikouensis is a recently described halotolerant bacterium isolated from paddy soil, able to grow on up to $17 \% \mathrm{NaCl}$ concentrations [46]. Oceanobacillus picturae 
Christakis et. al., Halophytic Endophytes in sustainable agriculture

is a halophilic phosphate-solubilizing species with demonstrated siderophore production potential that has been isolated from saline environments and has been shown to promote plant growth promotion in mangroves and confer salinity stress tolerance in barley [47-49]. Many of our isolates showed ability to grow at high concentrations of salt ( $5 \%$ to $17 \%$ salinity), while it is important to mention that the Mediterranean Sea salinity is around 3.8\%

Pseudomonas glareae, Enterobacter hormaechei, Pseudomonas benzenivorans, antagonistic activity against the phytopathogenic bacteria Ralstonia solanacearum and Clavibacter michiganensis subsp. michiganensis, two very important plant pathogens with high economic impact on agriculture $[50,51]$. Both are very important phytopathogens, since Ralstonia has a large host range able to infect more than 200 plant species easily adaptable in varying environmental conditions whereas $C$. michiganensis subsp. michiganensis is able to infect wheat, maize, potatoes and red and green peppers, despite its main host being tomatoes [51-53]. Moreover, a selected number of isolates that revealed in-vitro growth inhibition effect against $V$. dahliae, were also tested for their ability to inhibit $V$. dahliae inplanta. Several of these isolates revealed a very promising in-planta suppression effect of the polyphagous pathogen $V$. dahliae. Interestingly, isolates with strong in-vitro effect did not manage to inhibit $V$. dahliae in-planta but also isolates with medium or low in-vitro effect

670 revealed very strong in-planta $V$. dahliae growth inhibition. This data provide the proof of concept for our study but also indicate that in future studies we need to investigate all the

672 isolates regarding their in-planta antifungal and/or antibacterial growth inhibition capacity. 
Christakis et. al., Halophytic Endophytes in sustainable agriculture

675

676

677

678

679

680

681

682

683

684

685

686

687

688

689

690

691

692

693

694

695

696

697

698

a very small number isolates indicates the high potentiality that the wild halophytic endophytome has regarding the isolation and the identification of new microbial species with novel capacities, that could be beneficial for both Agriculture (biotic and a-biotic stress tolerance, growth promotion, etc.) and potentially in clinical practice (identification of new antibiotics, antifungal compounds, etc.).

The study of the endophytic microbes is now benefitting from a number of new culture methods and media, as well as, the rapid and efficient DNA based bacterial identification techniques and the total genome sequencing and annotation. The results of our study and the microbial collection we have generated, could be the basis for the future development of various synthetic "Bio-Inoculants". They can also be the basis for a number of future studies, including the investigation of the colonization strategies that these microbes use, as well as, the elucidation of the molecular dialogs that take place during host-root colonization; the growth promotion; the salt tolerance and the immunity activation, by unique beneficial endophytes or artificial endophytic communities.

The endophytes must possess following attributes for agricultural exploitation: a) they must not be pathogenic and must not induce plant disease; b) they should be capable to spread and colonize the plant tissues; c) they should be culturable in order to be used in modern agriculture and d) they must colonize plant parts and to be compatible with the species genetic characteristics.

For a new environmentally friendly global strategy in food production that will be based in the sustainable agriculture with low chemical inputs and a low environmental impact, there is a strong need to search for novel beneficial entophytic microbes with as many desirable characters for enhancing the crop production. For this, the halophytic endophytes could be a great source of beneficial microbes that could be a solution for agriculture in saline 
bioRxiv preprint doi: https://doi.org/10.1101/2020.07.29.226860; this version posted July 29, 2020. The copyright holder for this preprint (which was not certified by peer review) is the author/funder. All rights reserved. No reuse allowed without permission.

Christakis et. al., Halophytic Endophytes in sustainable agriculture

699 environments, as well as, a great source of microbes for biocontrol of important pathogens,

700 based on biological systems involving CWR plants well-adapted to grow in soils affected by

701 salinity and associated microorganisms are gaining interest.

702 
Christakis et. al., Halophytic Endophytes in sustainable agriculture

\section{Acknowledgements}

This project utilized equipment funded by the Wellcome Trust Institutional Strategic

705

Support Fund (WT097835MF), Wellcome Trust Multi-User Equipment Award (WT101650MA)

706 and BBSRC LOLA award (BB/K003240/1).

707 The authors acknowledge Dr. Karen Moore, Audrey Farbos, Georgina Morris of the sequencing.

710 This work benefitted from the support of the University of Exeter's High-Performance

711 Computing (HPC) facility.

712 The project was partially supported by the Emblematic Action of the Greek General

713 Secretariat for Research and Technology (GSRT), "AGRO4CRETE", Protocol Number: SAE 013, 
Christakis et. al., Halophytic Endophytes in sustainable agriculture

\section{References}

717 1. Ryan RP, Germaine K, Franks A, Ryan DJ, Dowling DN. Bacterial endophytes: Recent developments and applications. FEMS Microbiol Lett 2008; 278: 1-9.

2. Rodriguez PA, Rothballer M, Chowdhury SP, Nussbaumer T, Gutjahr C, Falter-Braun P. Systems Biology of Plant-Microbiome Interactions. Mol Plant 2019; 12: 804-821.

3. Edwards J, Johnson C, Santos-Medellín C, Lurie E, Podishetty NK, Bhatnagar S, et al. Structure, variation, and assembly of the root-associated microbiomes of rice. Proc Natl Acad Sci 2015; 112: E911-E920.

724

4. Toju H, Peay KG, Yamamichi M, Narisawa K, Hiruma K, Naito K, et al. Core microbiomes for sustainable agroecosystems. Nat Plants 2018; 4: 247-257.

5. Bulgarelli D, Garrido-Oter R, Münch PC, Weiman A, Dröge J, Pan Y, et al. Structure and function of the bacterial root microbiota in wild and domesticated barley. Cell Host Microbe 2015.

6. Bulgarelli D, Spaepen S, Schlaeppi K, Schulze-Lefert P, van Themaat EVL. Structure and Functions of the Bacterial Microbiota of Plants. Annu Rev Plant Biol 2013; 64: 807-838.

7. Liu H, Carvalhais LC, Crawford M, Singh E, Dennis PG, Pieterse CMJ, et al. Inner plant values: Diversity, colonization and benefits from endophytic bacteria. Front Microbiol 2017; 8: 1-17.

8. Rodríguez-Blanco A, Sicardi M, Frioni L. Plant genotype and nitrogen fertilization effects

9. Vaishnav A, Shukla AK, Sharma A, Kumar R, Choudhary DK. Endophytic Bacteria in Plant

10. Glick BR. Bacteria with ACC deaminase can promote plant growth and help to feed the

11. Tkacz A, Poole P. Role of root microbiota in plant productivity. J Exp Bot 2015; 66: 21672175.

12. Haney CH, Samuel BS, Bush J, Ausubel FM. Associations with rhizosphere bacteria can confer an adaptive advantage to plants. Nat Plants 2015; 1: 15051.

13. Marques JM, da Silva TF, Vollú RE, de Lacerda JRM, Blank AF, Smalla K, et al. Bacterial endophytes of sweet potato tuberous roots affected by the plant genotype and growth stage. Appl Soil Ecol 2015.

14. Pérez-Jaramillo JE, Mendes R, Raaijmakers JM. Impact of plant domestication on rhizosphere microbiome assembly and functions. Plant Mol Biol 2016; 90: 635-644.

15. Mendes R, Garbeva P, Raaijmakers JM. The rhizosphere microbiome: Significance of plant beneficial, plant pathogenic, and human pathogenic microorganisms. FEMS Microbiol Rev 2013; 37: 634-663.

16. Shabala S. Learning from halophytes: physiological basis and strategies to improve abiotic stress tolerance in crops. Ann Bot 2013; 112: 1209-1221.

17. Ruppel S, Franken P, Witzel K. Properties of the halophyte microbiome and their 
Christakis et. al., Halophytic Endophytes in sustainable agriculture

implications for plant salt tolerance. Funct Plant Biol 2013.

18. Yuan Z, Druzhinina IS, Labbé J, Redman R, Qin Y, Rodriguez R, et al. Specialized microbiome of a halophyte and its role in helping non-host plants to withstand salinity. Sci Rep 2016; 6.

19. Etesami H, Beattie GA. Mining halophytes for plant growth-promoting halotolerant bacteria to enhance the salinity tolerance of non-halophytic crops. Front Microbiol 2018; 9.

20. White TJ, Bruns T, Lee S, Taylor J. Amplification and Direct Sequencing of Fungal Ribosomal Rna Genes for Phylogenetics: PCR - Protocols and Applications - A Laboratory Manual. PCR Protocols: A Guide to Methods and Applications . 1990.

21. Lane JD. 16S/23S rRNA sequencing. In: Stackebrandt E, Goodfellow M (eds). Nucleic acid techniques in bacterial systematics. 1991. John Wiley \& Sons Ltd., pp 115-175.

22. Kumar S, Stecher G, Li M, Knyaz C, Tamura K. MEGA X: Molecular Evolutionary Genetics Analysis across Computing Platforms. Mol Biol Evol 2018; 35: 1547-1549.

23. Quast $C$, Pruesse E, Yilmaz P, Gerken J, Schweer T, Yarza P, et al. The SILVA ribosomal RNA gene database project: improved data processing and web-based tools. Nucleic Acids Res 2013; 41: D590-6.

24. Yoon SH, Ha SM, Kwon S, Lim J, Kim Y, Seo H, et al. Introducing EzBioCloud: A taxonomically united database of 16S rRNA gene sequences and whole-genome assemblies. Int J Syst Evol Microbiol 2017; 67: 1613-1617.

25. Chaurasia B, Pandey A, Palni LMS, Trivedi P, Kumar B, Colvin N. Diffusible and volatile compounds produced by an antagonistic Bacillus subtilis strain cause structural deformations in pathogenic fungi in vitro. Microbiol Res 2005; 160: 75-81.

26. Markakis EA, Fountoulakis MS, Daskalakis GC, Kokkinis M, Ligoxigakis EK. The suppressive effect of compost amendments on Fusarium oxysporum f.sp. radiciscucumerinum in cucumber and Verticillium dahliae in eggplant. Crop Prot 2016; 79: 7079.

27. Campbell C, Madden L. Introduction to plant disease epidemiology. 1990.

28. Pegg GF, Brady BL. Verticillium wilts. 2002. CABI.

29. Bankevich A, Nurk S, Antipov D, Gurevich AA, Dvorkin M, Kulikov AS, et al. SPAdes: a new genome assembly algorithm and its applications to single-cell sequencing. $J$ Comput Biol 2012.

30. Leinonen R, Sugawara H, Shumway M. The Sequence Read Archive. Nucleic Acids Res 2011; 39: D19-D21.

31. Benson DA, Cavanaugh M, Clark K, Karsch-Mizrachi I, Ostell J, Pruitt KD, et al. GenBank. Nucleic Acids Res 2018; 46: D41-D47.

32. Overbeek R, Olson R, Pusch GD, Olsen GJ, Davis JJ, Disz T, et al. The SEED and the Rapid Annotation of microbial genomes using Subsystems Technology (RAST). Nucleic Acids Res 2014.

33. Larkin MA, Blackshields G, Brown NP, Chenna R, Mcgettigan PA, McWilliam H, et al. Clustal $W$ and Clustal $X$ version 2.0. Bioinformatics 2007. 
Christakis et. al., Halophytic Endophytes in sustainable agriculture

34. Tamura K, Peterson D, Peterson N, Stecher G, Nei M, Kumar S. MEGA5: Molecular Evolutionary Genetics Analysis Using Maximum Likelihood, Evolutionary Distance, and Maximum Parsimony Methods. Mol Biol Evol 2011; 28: 2731-2739.

35. Saikkonen K, Faeth SH, Helander M, Sullivan TJ. Fungal endophytes: A continuum of interactions with host plants. Annu Rev Ecol Syst 1998.

36. Kaul S, Sharma T, K. Dhar M. "Omics" Tools for Better Understanding the PlantEndophyte Interactions. Front Plant Sci 2016; 7: 1-9.

37. Hasegawa S, Meguro A, Shimizu M, Nishimura T, Kunoh H. Endophytic Actinomycetes and Their Interactions with Host Plants. Actinomycetologica 2006; 20: 72-81.

38. Liu H, Brettell LE, Qiu Z, Singh BK. Microbiome-Mediated Stress Resistance in Plants. Trends Plant Sci 2020; 25: 733-743.

39. Pascale A, Proietti S, Pantelides IS, Stringlis IA. Modulation of the Root Microbiome by Plant Molecules: The Basis for Targeted Disease Suppression and Plant Growth Promotion. Front Plant Sci 2020; 10: 1741.

40. Qin S, Zhang YJ, Yuan B, Xu PY, Xing K, Wang J, et al. Isolation of ACC deaminaseproducing habitat-adapted symbiotic bacteria associated with halophyte Limonium sinense (Girard) Kuntze and evaluating their plant growth-promoting activity under salt stress. Plant Soil 2014; 374: 753-766.

41. Mora-Ruiz MDR, Font-Verdera F, Orfila A, Rita J, Rosselĺo-Ḿora R. Endophytic microbial diversity of the halophyte Arthrocnemum macrostachyum across plant compartments. FEMS Microbiol Ecol 2016.

42. An SY, Asahara M, Goto K, Kasai H, Yokota A. Terribacillus saccharophilus gen. nov., sp. nov. and Terribacillus halophilus sp. nov., spore-forming bacteria isolated from field soil in Japan. Int J Syst Evol Microbiol 2007; 57: 51-55.

43. Liu W, Jiang L, Guo C, Yang SS. Terribacillus aidingensis sp. nov., a moderately halophilic bacterium. Int J Syst Evol Microbiol 2010; 60: 2940-2945.

44. Han J, Song Y, Liu Z, Hu Y. Culturable bacterial community analysis in the root domains of two varieties of tree peony (Paeonia ostii). FEMS Microbiol Lett 2011; 322: 15-24.

45. Salomon MV, Purpora R, Bottini R, Piccoli P. Rhizosphere associated bacteria trigger accumulation of terpenes in leaves of Vitis vinifera L. cv. Malbec that protect cells against reactive oxygen species. Plant Physiol Biochem 2016; 106: 295-304.

46. Li J, Yang G, Lu Q, Zhao Y, Zhou S. Bacillus haikouensis sp. nov., a facultatively anaerobic halotolerant bacterium isolated from a paddy soil. Antonie van Leeuwenhoek, Int J Gen Mol Microbiol 2014; 106: 789-794.

47. El-Tarabily KA, Youssef T. Enhancement of morphological, anatomical and physiological characteristics of seedlings of the mangrove Avicennia marina inoculated with a native phosphate-solubilizing isolate of Oceanobacillus picturae under greenhouse conditions. Plant Soil 2010; 332: 147-162.

48. Orhan F, Demirci A. Salt Stress Mitigating Potential of Halotolerant/Halophilic Plant Growth Promoting. Geomicrobiol J 2020; 1-7.

49. Mapelli F, Marasco R, Rolli E, Barbato M, Cherif H, Guesmi A, et al. Potential for plant 
Christakis et. al., Halophytic Endophytes in sustainable agriculture

growth promotion of rhizobacteria associated with Salicornia growing in Tunisian hypersaline soils. Biomed Res Int 2013; 2013.

50. Gartemann KH, Kirchner O, Engemann J, Gräfen I, Eichenlaub R, Burger A. Clavibacter michiganensis subsp. michiganensis: First steps in the understanding of virulence of a Gram-positive phytopathogenic bacterium. J Biotechnol 2003.

51. Peeters N, Guidot A, Vailleau F, Valls M. Ralstonia solanacearum, a widespread bacterial plant pathogen in the post-genomic era. Mol Plant Pathol 2013; 14: 651-662.

52. Hwang IS, Oh EJ, Kim D, Oh CS. Multiple plasmid-borne virulence genes of Clavibacter michiganensis ssp. capsici critical for disease development in pepper. New Phytol 2018.

53. Eichenlaub R, Gartemann K-H. The Clavibacter michiganensis Subspecies: Molecular Investigation of Gram-Positive Bacterial Plant Pathogens. Annu Rev Phytopathol 2011.

54. Tamura K, Nei M. Estimation of the number of nucleotide substitutions in the control region of mitochondrial DNA in humans and chimpanzees. Mol Biol Evol 1993; 10: 512526.

55. Felsenstein J. Confidence Limits on Phylogenies: An Approach Using the Bootstrap. Evolution (N Y) 1985; 39: 783.

56. Markakis EA, Tjamos SE, Antoniou PP, Paplomatas EJ, \& Tjamos EC. Biological control of Verticillium wilt of olive by Paenibacillus alvei, strain K165. BioControl 2016; 61:293303.

57. Fadiji AE. and Babalola OO. Elucidating Mechanisms of Endophytes Used in Plant Protection and Other Bioactivities With Multifunctional Prospects. Front. Bioeng. Biotechnol. 2020; 8:467.

58 Mercado-Blanco J. and Lugtenberg BJJ. Biotechnological Applications of Bacterial Endophytes. Current Biotechnology 2014; 3:60-75. 
Christakis et. al., Halophytic Endophytes in sustainable agriculture

Figures

Figure 1. Abundance of genera of bacterial isolates obtained from leaves and roots of

Matthiola tricuspidata, Crithmum maritimum and Cakile maritima plants.

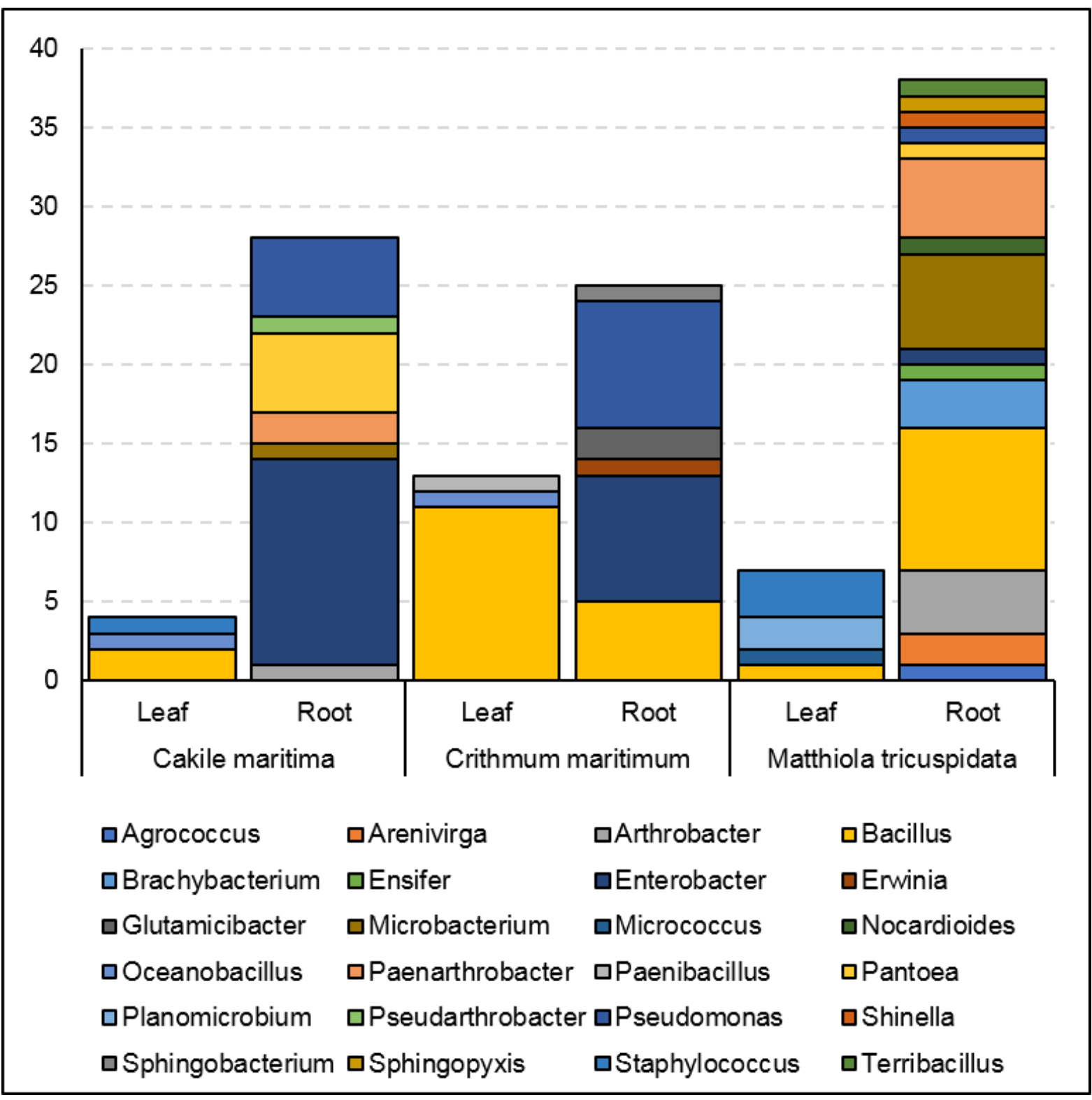


Christakis et. al., Halophytic Endophytes in sustainable agriculture

Figure 2. In vitro growth inhibition experiments: against phytopathogenic bacteria Ralstonia

873 (A3, B3, C3) inhibitory activity.
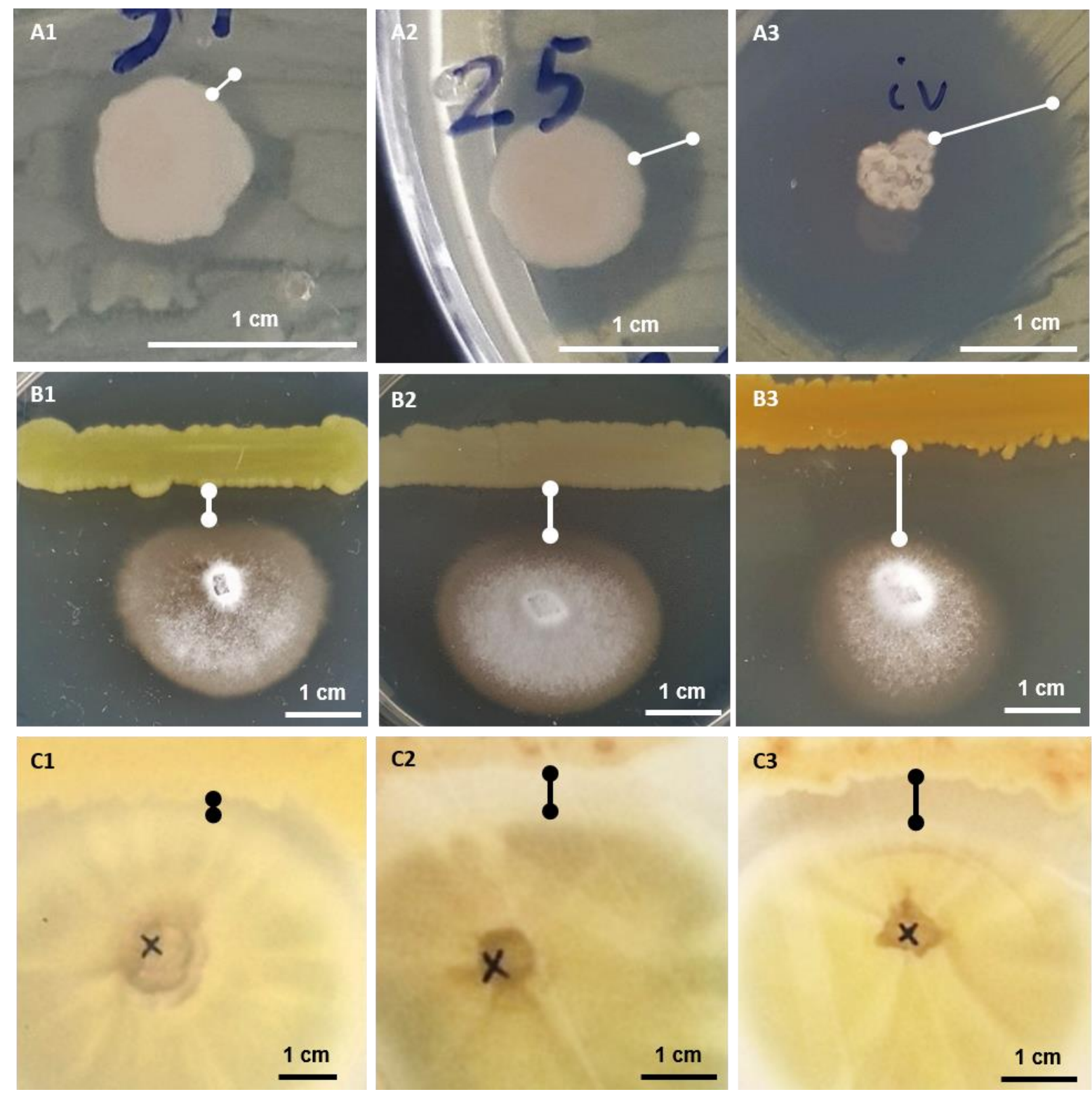
bioRxiv preprint doi: https://doi.org/10.1101/2020.07.29.226860; this version posted July 29, 2020. The copyright holder for this preprint (which was not certified by peer review) is the author/funder. All rights reserved. No reuse allowed without permission.

Christakis et. al., Halophytic Endophytes in sustainable agriculture

876

Figure 3. Verticillium wilt disease severity index on eggplant treated with various bacterial

877 strains at $12,14,18,21$ and 24 days post inoculation with Verticillium dahliae conidial

878 suspension $\left(20 \mathrm{ml}\right.$ of $5 \times 10^{6}$ conidia $\left.\mathrm{ml}^{-1}\right)$. Each column represents the mean of 21 plants after

879 combining the results of 3 replicated experiments (experiment 1). Columns at each

880 observation time point followed by the same letter are not significantly different according

881 to Tukey's HSD test at $P \leq 0.05$. Vertical bars indicate standard errors.

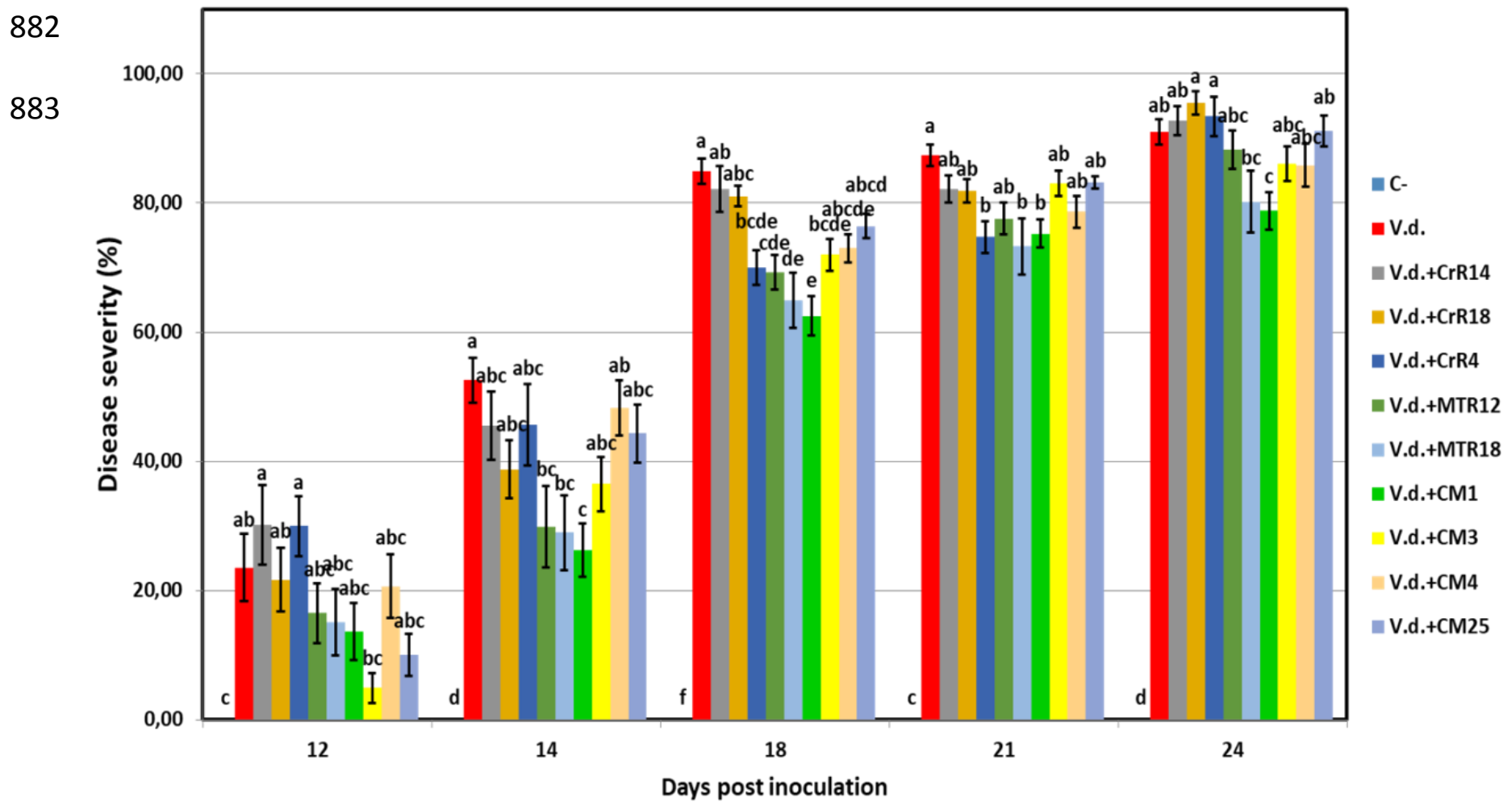


bioRxiv preprint doi: https://doi.org/10.1101/2020.07.29.226860; this version posted July 29, 2020. The copyright holder for this preprint (which was not certified by peer review) is the author/funder. All rights reserved. No reuse allowed without permission.

Christakis et. al., Halophytic Endophytes in sustainable agriculture

884

Figure 4. Verticillium wilt disease severity index on eggplant treated with various bacterial

885 strains and the commercial biofungicide TRIANUM-P (Koppert B.V. Hellas) at 12, 14, 16, 19,

$88623,26,28$ and 30 days post inoculation with Verticillium dahliae conidial suspension ( $20 \mathrm{ml}$ of

$8875 \times 106$ conidia $\mathrm{ml}-1$ ). Each column represents the mean of 21 plants after combining the

888 results of 3 replicated experiments (experiment II). Columns at each observation time point

889 followed by the same letter are not significantly different according to Tukey's HSD test at P

$890 \leq 0.05$. Vertical bars indicate standard errors.

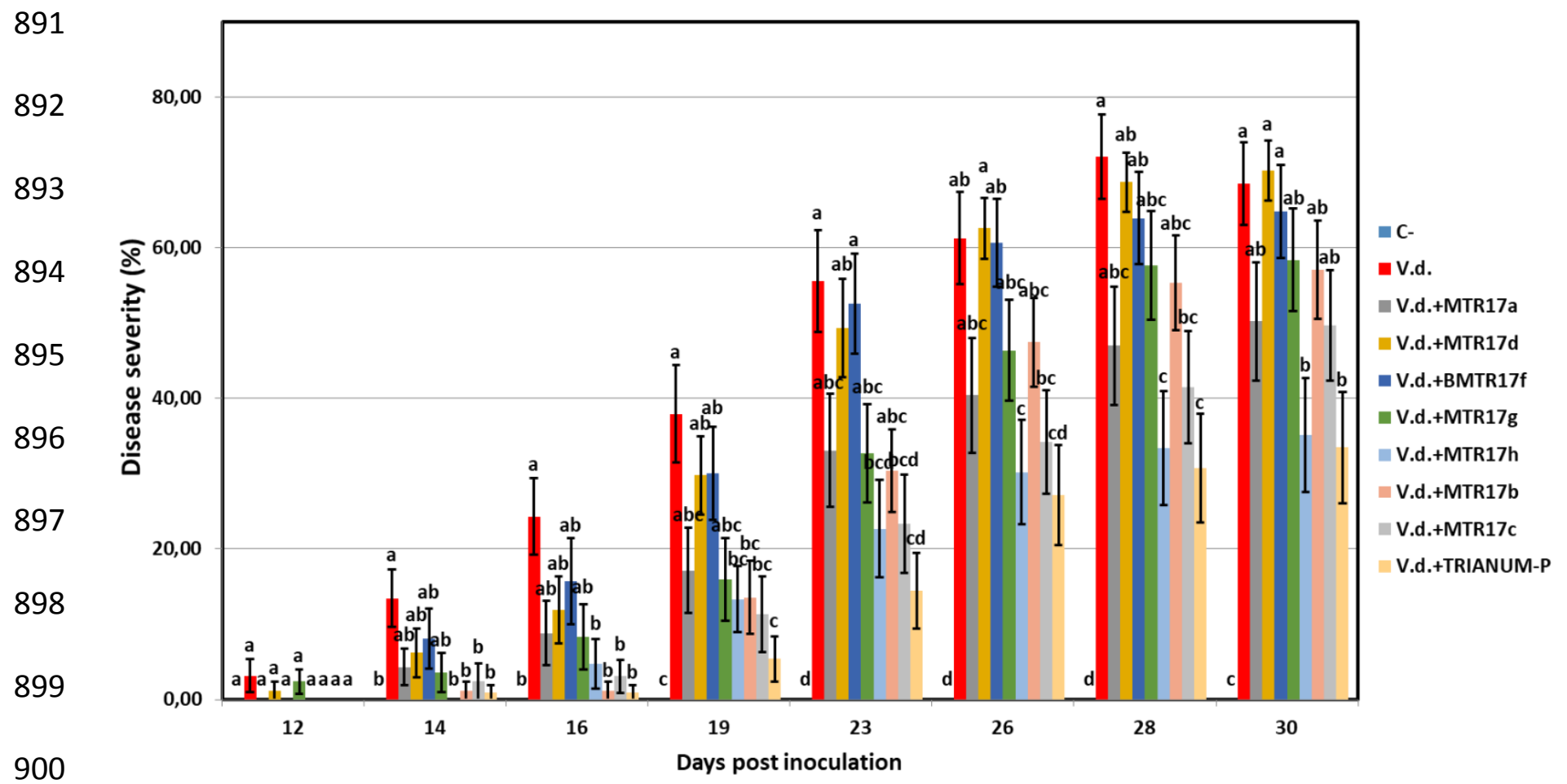


bioRxiv preprint doi: https://doi.org/10.1101/2020.07.29.226860; this version posted July 29, 2020. The copyright holder for this preprint (which was not certified by peer review) is the author/funder. All rights reserved. No reuse allowed without permission.

Christakis et. al., Halophytic Endophytes in sustainable agriculture

901

Figure 5. Verticillium wilt symptoms on eggplants treated with various bacterial strains and

902

the commercial biofungicide TRIANUM-P (Koppert B.V. Hellas). A: mock inoculated plants

903

treated with water (negative controls); B: Verticillium dahliae-inoculated plants with no other

904

treatment (positive controls), C: $V$. dahliae-inoculated plants treated with the non-

suppressive bacterial strain Mtr17d; D and E: $V$. dahliae-inoculated plants treated with the

906

disease-suppressive strains Mtr17h and Mtr17c, respectively; F: V. dahliae-inoculated plants

907

treated with the disease-suppressive biofungicide TRIANUM-P.
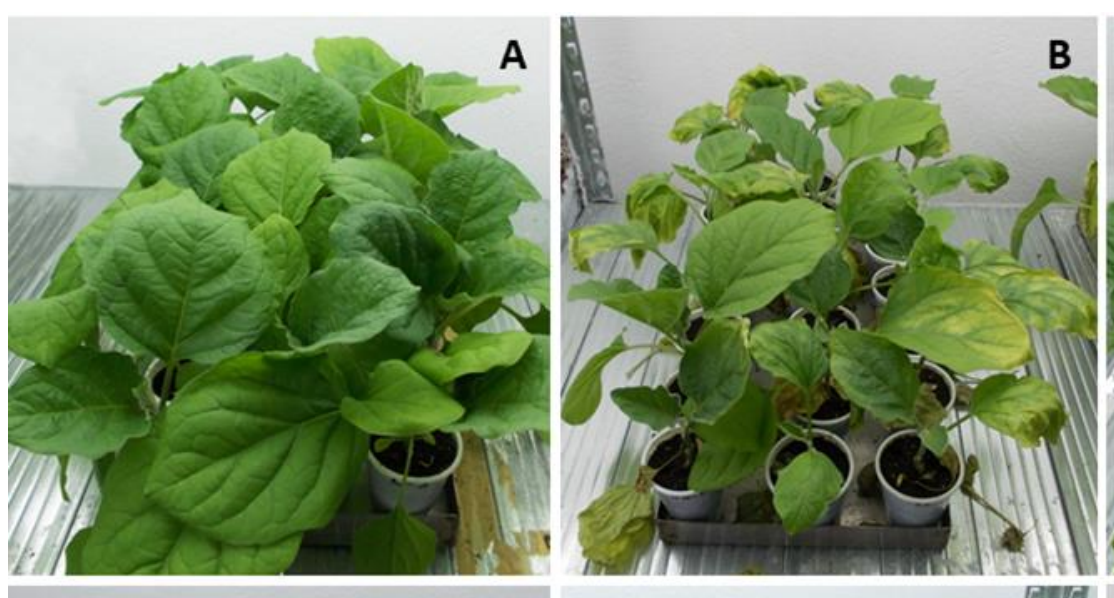

B
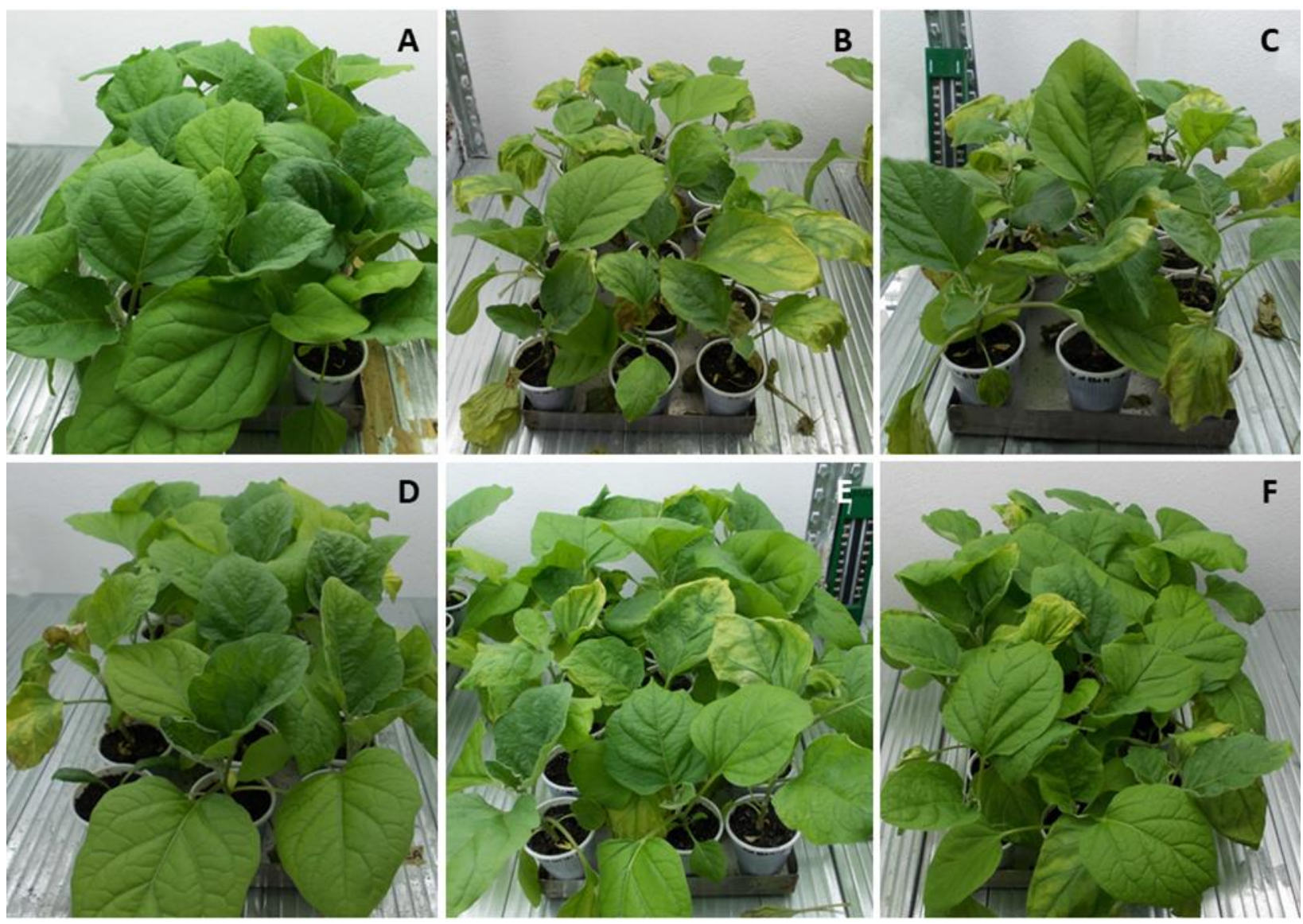
bioRxiv preprint doi: https://doi.org/10.1101/2020.07.29.226860; this version posted July 29, 2020. The copyright holder for this preprint (which was not certified by peer review) is the author/funder. All rights reserved. No reuse allowed without permission.

Christakis et. al., Halophytic Endophytes in sustainable agriculture

910 Figure 6. Molecular Phylogenetic analysis of Arthrobacter recA-gyrB genes by Maximum

911 Likelihood method. The evolutionary history was inferred by using the Maximum Likelihood

912 method based on the Tamura-Nei model [54]. The bootstrap consensus tree inferred from

913500 replicates [55] is taken to represent the evolutionary history of the taxa analyzed [55].

914 Branches corresponding to partitions reproduced in less than $50 \%$ bootstrap replicates are

915 collapsed. Initial tree(s) for the heuristic search were obtained automatically as follows. When

916 the number of common sites was $<100$ or less than one fourth of the total number of sites,

917 the maximum parsimony method was used; otherwise BIONJ method with MCL distance

918 matrix was used. The tree is drawn to scale, with branch lengths measured in the number of

919 substitutions per site. The analysis involved 25 nucleotide sequences. Codon positions

920 included were $1 s t+2 n d+3 r d+$ Noncoding. All positions with less than $95 \%$ site coverage were

921 eliminated. That is, fewer than 5\% alignment gaps, missing data, and ambiguous bases were

922 allowed at any position. Evolutionary analyses were conducted in MEGA5 [34]. 
bioRxiv preprint doi: https://doi.org/10.1101/2020.07.29.226860; this version posted July 29, 2020. The copyright holder for this preprint (which was not certified by peer review) is the author/funder. All rights reserved. No reuse allowed without permission.

Christakis et. al.,

924

925

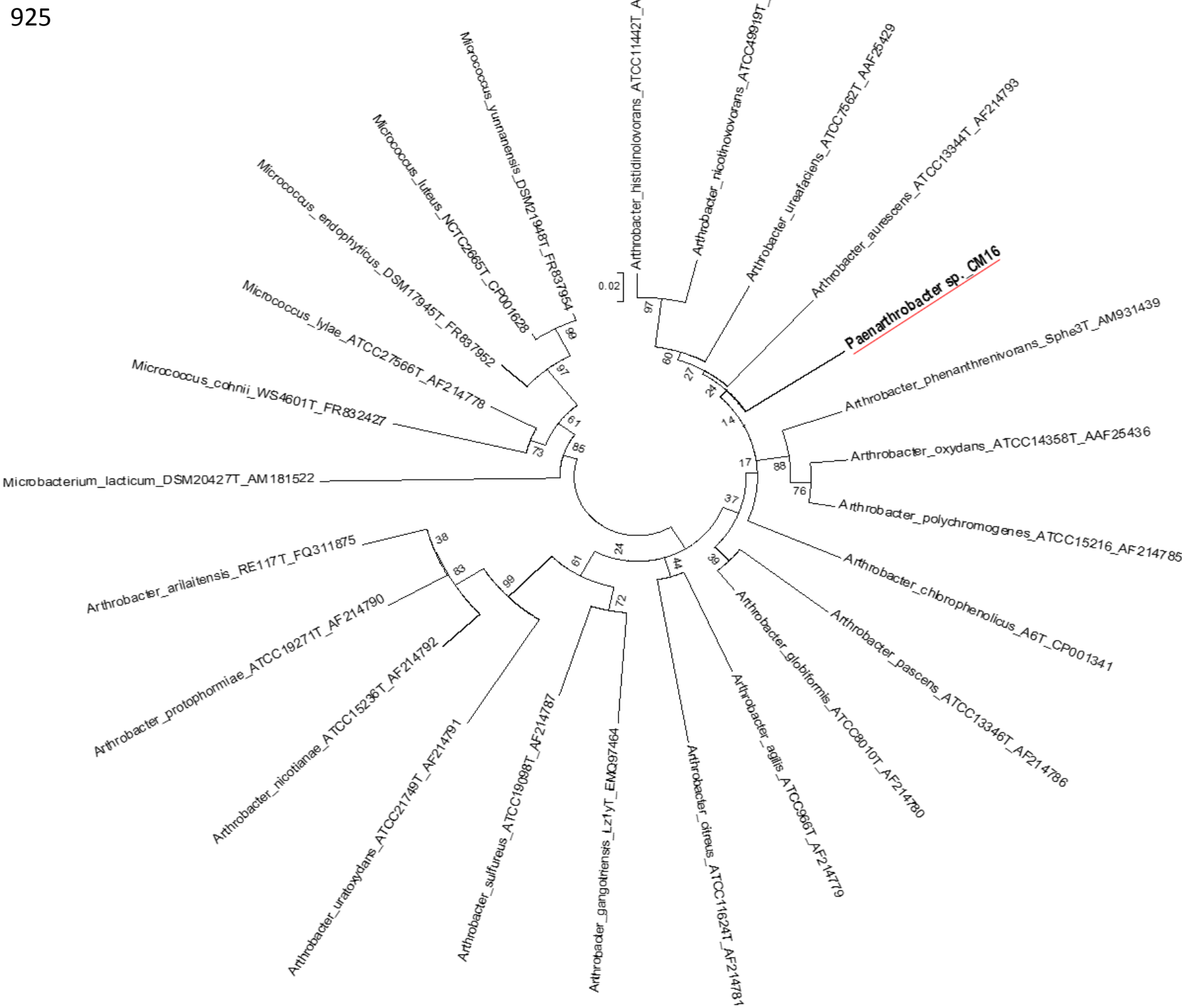


bioRxiv preprint doi: https://doi.org/10.1101/2020.07.29.226860; this version posted July 29, 2020. The copyright holder for this preprint (which was not certified by peer review) is the author/funder. All rights reserved. No reuse allowed without permission.

Christakis et. al., Halophytic Endophytes in sustainable agriculture

Figure 7. Molecular Phylogenetic analysis of the recA-gyrB genes from Pseudomonads

927 belonging to $P$. putida and $P$. mendocina groups by Maximum Likelihood method. The

928 evolutionary history was inferred by using the Maximum Likelihood method based on the

929 Tamura-Nei model [54]. The tree with the highest log likelihood (-7831.6808) is shown. Initial

930 tree(s) for the heuristic search were obtained automatically as follows. When the number of

931 common sites was $<100$ or less than one fourth of the total number of sites, the maximum

932 parsimony method was used; otherwise BIONJ method with MCL distance matrix was used.

933 The bootstrap consensus tree inferred from 500 replicates [55] is taken to represent the

934 evolutionary history of the taxa analyzed [55]. The tree is drawn to scale, with branch lengths

935 measured in the number of substitutions per site. The analysis involved 22 nucleotide

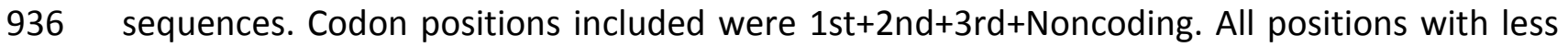

937 than $95 \%$ site coverage were eliminated. That is, fewer than $5 \%$ alignment gaps, missing data,

938 and ambiguous bases were allowed at any position. Evolutionary analyses were conducted in

939 MEGA5 [34].

940 
bioRxiv preprint doi: https://doi.org/10.1101/2020.07.29.226860; this version posted July 29, 2020. The copyright holder for this preprint (which was not certified by peer review) is the author/funder. All rights reserved. No reuse allowed without permission.

Christakis et. al.,

941

942

943

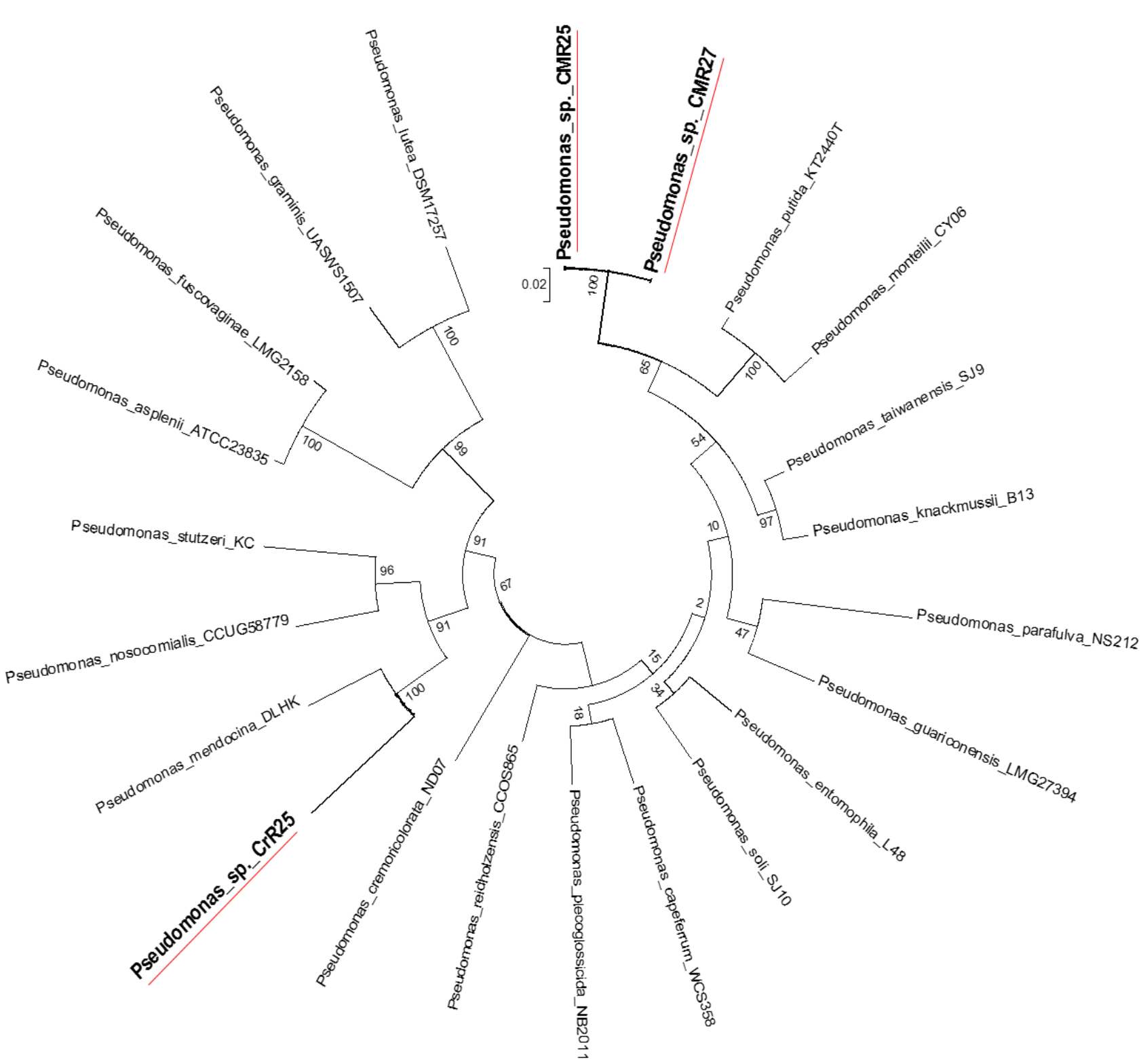

Halophytic Endophytes in sustainable agriculture 
bioRxiv preprint doi: https://doi.org/10.1101/2020.07.29.226860; this version posted July 29,2020 . The copyright holder for this preprint (which was not certified by peer review) is the author/funder. All rights reserved. No reuse allowed without permission.

Christakis et. al., Halophytic Endophytes in sustainable agriculture

944

\section{Tables}

945 Table 1. In planta plant growth promotion and salt tolerance assays in Arabidopsis thaliana

946 plants. Plants were watered with selected halotolerant strains and with and without $\mathrm{NaCl}$

947 solution every 2-3 days for 30 days and fresh and dry leaf weight was measured.

\begin{tabular}{lccc|cc} 
& & \multicolumn{2}{c}{ Plant growth promotion assay } & \multicolumn{2}{c}{ Salinity stress assay } \\
\cline { 3 - 6 } Host Plant & Strain & Fresh weight & Dry weight & Fresh weight & Dry weight \\
\hline Cakile maritima & CML12 & 0.410 & 0.029 & 0.246 & 0.034 \\
Cakile maritima & CML15 & 0.204 & 0.025 & 0.309 & 0.052 \\
Cakile maritima & CMR13 & 0.144 & 0.022 & 0.239 & 0.032 \\
Crithmum maritimum & CrL01 & 0.541 & 0.053 & 0.147 & 0.031 \\
Crithmum maritimum & CrL04 & 0.149 & 0.019 & 0.197 & 0.031 \\
Crithmum maritimum & CrL11 & 0.242 & 0.026 & 0.236 & 0.034 \\
Crithmum maritimum & CrR16 & 0.277 & 0.026 & 0.165 & 0.031 \\
Crithmum maritimum & CrR22 & 0.094 & 0.016 & 0.275 & 0.042 \\
Crithmum maritimum & CrR23 & 0.170 & 0.023 & 0.103 & 0.026 \\
Matthiola tricuspidata & MTL01 & 0.113 & 0.017 & 0.202 & 0.037 \\
Matthiola tricuspidata & MTR05 & 0.169 & 0.028 & 0.322 & 0.056 \\
Matthiola tricuspidata & MTR27 & 0.114 & 0.015 & 0.213 & 0.033 \\
& Control E. coli & 0.110 & 0.017 & 0.235 & 0.034 \\
& Control H2O & 0.156 & 0.023 & 1.266 & 0.094 \\
& Control Salt & N/A & N/A & 0.25 & 0.034
\end{tabular}

948

949

950

951

952

953

954

955

956

957 
958 Table 2. Values of fungal parameters of Verticillium dahliae treated with 16 different bacterial strains (CrR14, CrR18, CrR4, MTR12, MTR18, CM1,

959 CM3, CM4, CM25, MTR17a, MTR17d, MTR17f, MTR17g, MTR17h, MTR17b, MTR17c) and Trichoderma harzianum strain T22 in dual-culture and

960 dual-plate assays. Values were estimated as the percentage of inhibition compared to control (V.d.)

\begin{tabular}{|c|c|c|c|c|c|c|c|c|}
\hline \multirow[t]{3}{*}{ Treatment } & \multicolumn{8}{|c|}{ Fungal parameters $^{a}$} \\
\hline & \multicolumn{4}{|c|}{ Dual-culture assays (confrontation test) } & \multicolumn{4}{|c|}{ Dual-plate assays (volatile test) } \\
\hline & RGI (\%) & SI (\%) & HWT $(\%)^{b}$ & MFI (\%) & RGI (\%) & SI (\%) $)^{d}$ & HWT (\%) & $\operatorname{MFI}(\%)^{f}$ \\
\hline V.d. & $0.00 \mathrm{~h}$ & $0.00 \mathrm{e}$ & $0.00 \mathrm{~d}$ & $0.00 \mathrm{f}$ & 0.00 cde & $0.00 \mathrm{~b}$ & $0.00 \mathrm{de}$ & 0.00 cde \\
\hline V.d.+CrR14 & $52.92 \mathrm{c}$ & $70.87 \mathrm{~cd}$ & $25.21 \mathrm{abc}$ & $68.98 \mathrm{ab}$ & $8.75 \mathrm{c}$ & $83.08 \mathrm{a}$ & $18.46 \mathrm{abcd}$ & $13.56 \mathrm{bcd}$ \\
\hline V.d.+CrR18 & $76.78 \mathrm{~b}$ & $57.11 \mathrm{~d}$ & $33.53 \mathrm{a}$ & 52.41 bcde & -1.97 cde & $79.68 \mathrm{a}$ & $22.33 a b$ & $24.99 \mathrm{cde}$ \\
\hline V.d.+CrR4 & $45.73 \mathrm{~cd}$ & $74.30 \mathrm{bc}$ & $20.56 \mathrm{abcd}$ & 47.88 bcde & $4.66 \mathrm{~cd}$ & $21.84 a b$ & $21.09 a b c$ & $71.91 \mathrm{ab}$ \\
\hline V.d.+MTR12 & 23.97 ef & $92.94 \mathrm{a}$ & $22.92 \mathrm{abc}$ & $26.65 \mathrm{cdef}$ & -3.83 cde & $82.75 \mathrm{a}$ & 25.99 a & $-20.10 \mathrm{cde}$ \\
\hline V.d.+MTR18 & $33.95 \mathrm{de}$ & 89.36 bc & $23.49 a b c$ & 34.23 bcdef & -2.78 cde & $83.13 \mathrm{a}$ & $30.95 \mathrm{a}$ & -1.86 cde \\
\hline V.d.+CM1 & $21.91 \mathrm{ef}$ & $81.46 \mathrm{abc}$ & $30.26 a b$ & $60.41 \mathrm{abcd}$ & -1.54 cde & $84.81 \mathrm{a}$ & $30.72 \mathrm{a}$ & $-25.08 \mathrm{cde}$ \\
\hline V.d.+CM3 & 27.22 ef & $88.34 \mathrm{abc}$ & $17.56 \mathrm{abcd}$ & 47.42 bcde & $7.70 \mathrm{c}$ & $56.63 \mathrm{ab}$ & $21.45 \mathrm{abc}$ & $42.98 \mathrm{abc}$ \\
\hline V.d.+CM4 & $59.69 \mathrm{c}$ & $70.31 \mathrm{~cd}$ & $18.10 \mathrm{abcd}$ & $65.11 \mathrm{abc}$ & -1.10 cde & 78.68 a & $28.22 \mathrm{a}$ & -32.44 de \\
\hline V.d.+CM25 & 23.15 ef & $79.00 \mathrm{abc}$ & $13.67 \mathrm{abcd}$ & 23.94 def & -3.58 cde & $70.63 a b$ & $17.55 \mathrm{abcd}$ & $-12.64 \mathrm{cde}$ \\
\hline V.d.+MTR17a & $45.22 \mathrm{~cd}$ & $82.66 \mathrm{abc}$ & $6.89 \mathrm{~cd}$ & $22.63 \mathrm{def}$ & $-8.86 \mathrm{de}$ & $-100.42 c$ & $-5.11 \mathrm{e}$ & $-43.35 \mathrm{~cd}$ \\
\hline V.d.+MTR17d & $45.85 \mathrm{~cd}$ & $83.99 a b c$ & $5.56 \mathrm{ab}$ & 32.93 bcdef & $3.31 \mathrm{~cd}$ & $74.61 \mathrm{ab}$ & $-3.78 \mathrm{e}$ & -2.18 de \\
\hline V.d.+MTR17f & $51.46 \mathrm{c}$ & $74.21 \mathrm{bc}$ & $10.89 \mathrm{bcd}$ & $18.77 a b$ & $-16.21 \mathrm{e}$ & $77.33 a b$ & $1.56 \mathrm{de}$ & $-60.99 e$ \\
\hline V.d.+MTR17g & $16.75 \mathrm{fg}$ & $5.29 \mathrm{e}$ & $21.33 a b c$ & $62.41 \mathrm{abcd}$ & -4.50 cde & $38.33 a b$ & $3.00 \mathrm{cde}$ & -2.99 cde \\
\hline V.d.+MTR17h & $2.86 \mathrm{gh}$ & $70.53 \mathrm{~cd}$ & $5.59 \mathrm{~cd}$ & $-67.79 \mathrm{~g}$ & $55.99 \mathrm{~b}$ & $-116.97 c$ & 5.59 bcde & $-298.98 f$ \\
\hline V.d.+MTR17b & $49.02 \mathrm{~cd}$ & $81.79 a b c$ & $0.58 d$ & $22.91 \mathrm{def}$ & $74.57 \mathrm{a}$ & $-120.55 c$ & $0.58 \mathrm{de}$ & $97.83 \mathrm{a}$ \\
\hline V.d.+MTR17c & $60.21 c$ & $91.26 \mathrm{a}$ & $7.60 \mathrm{~cd}$ & 24.02 def & $69.06 \mathrm{ab}$ & $-88.87 c$ & 6.35 bcde & $99.28 \mathrm{a}$ \\
\hline V.d.+TRIANUM-P & $95.79 \mathrm{a}$ & $79.46 \mathrm{abc}$ & $\mathrm{nm}$ & $98.91 \mathrm{a}$ & ne & ne & ne & ne \\
\hline
\end{tabular}

961 a Fungal parameters were calculated according to the formula: $((\mathrm{Vc}-\mathrm{Vt}) / \mathrm{Vc}) \times 100$ where $\mathrm{V}_{\mathrm{c}}=$ the microscopic value of $V$. dahliae in control and $\mathrm{Vt}=$ the respective value of $V$.

962 dahliae towards the antagonistic strain in dual-culture or dual-plate assays. Each value represents the mean of 3 replicates. RGI=radial growth inhibition; SI=sporulation 
(spore production) inhibition; HWT=hyphae width thinning; MFI=microsclerotia formation inhibition. Within columns, values followed by the same letter are not significantly different according to Tukey's HSD test at $P \leq 0.05$

b ' $n$ m' indicates that HWT values were not measured since $T$. harzianum overgrown $V$. dahliae in dual-culture assays and pathogen hyphae could not be identified

c, d,e, f 'ne' indicates that RGI, SI, HWT and MFI were not estimated since $T$. harzianum could reach directly $V$. dahliae even in dual-plate assays 
977 Table 3. Values ( \pm standard errors) of disease parameters for eggplants inoculated with $V$. dahliae and treated with different bacterial strains and

978 TRIANUM-P (CrR14, CrR18, CrR4, MTR12, MTR18, CM1, CM3, CM4, CM25 in experiment I, and MTR17a, MTR17d, MTR17f, MTR17g, MTR17h,

979 MTR17b, MTR17c, TRIANUM-P in experiment II) or not (C-, V.d.)

\begin{tabular}{|c|c|c|c|c|c|c|}
\hline \multirow[t]{2}{*}{ Experiment } & \multirow[t]{2}{*}{ Treatment } & \multicolumn{5}{|c|}{ Disease parameters $^{a}$} \\
\hline & & DI (\%) & FDS (\%) & M (\%) & RAUDPC (\%) & $\mathbf{I R}$ \\
\hline \multirow{11}{*}{ Experiment I } & C- & $0.00 \pm 0.00 \mathrm{~b}$ & $0.00 \pm 0.00 \mathrm{c}$ & $0.00 \pm 0.00 \mathrm{c}$ & $0.00 \pm 0.00 \mathrm{c}$ & $0.00 \pm 0.00 \mathrm{~b}$ \\
\hline & V.d. & $100.00 \pm 0.00 \mathrm{a}$ & $91.00 \pm 1.91 \mathrm{ab}$ & $100.00 \pm 0.00 \mathrm{a}$ & $42.36 \pm 2.08 \mathrm{a}$ & $0.55 \pm 0.07 a b$ \\
\hline & V.d.+CrR14 & $100.00 \pm 0.00 \mathrm{a}$ & $92.74 \pm 2.21 \mathrm{ab}$ & $95.24 \pm 4.76 \mathrm{a}$ & $42.54 \pm 2.62 \mathrm{a}$ & $0.65 \pm 0.05 \mathrm{a}$ \\
\hline & V.d.+CrR18 & $100.00 \pm 0.00 \mathrm{a}$ & $95.50 \pm 1.80 \mathrm{a}$ & $90.48 \pm 6.15 a b$ & $39.19 \pm 1.99 a b$ & $0.55 \pm 0.08 a b$ \\
\hline & V.d.+CrR4 & $100.00 \pm 0.00 \mathrm{a}$ & $93.40 \pm 2.99 \mathrm{a}$ & $78.57 \pm 7.70 \mathrm{ab}$ & $39.84 \pm 2.18 \mathrm{ab}$ & $0.60 \pm 0.05 a b$ \\
\hline & V.d.+MTR12 & $100.00 \pm 0.00 \mathrm{a}$ & $88.29 \pm 2.74 a b c$ & $80.95 \pm 9.91 a b$ & $33.86 \pm 2.59 a b$ & $0.80 \pm 0.07 a$ \\
\hline & V.d.+MTR18 & $100.00 \pm 0.00 \mathrm{a}$ & $80.19 \pm 4.75 b c$ & $71.43 \pm 8.69 a b$ & $31.67 \pm 3.02 \mathrm{~b}$ & $0.55 \pm 0.05 a b$ \\
\hline & V.d.+CM1 & $100.00 \pm 0.00 \mathrm{a}$ & $78.79 \pm 2.85 c$ & $52.38 \pm 14.29 b$ & $30.72 \pm 2.18 b$ & $0.55 \pm 0.08 \mathrm{ab}$ \\
\hline & V.d.+CM3 & $100.00 \pm 0.00 \mathrm{a}$ & $86.07 \pm 2.71 \mathrm{abc}$ & $66.67 \pm 14.55 \mathrm{ab}$ & $32.25 \pm 1.47 \mathrm{~b}$ & $0.65 \pm 0.08 a$ \\
\hline & V.d.+CM4 & $100.00 \pm 0.00 \mathrm{a}$ & $85.82 \pm 3.34 \mathrm{abc}$ & $69.05 \pm 5.67 \mathrm{ab}$ & $37.91 \pm 2.00 \mathrm{ab}$ & $0.65 \pm 0.05 a$ \\
\hline & V.d.+CM 25 & $100.00 \pm 0.00 \mathrm{a}$ & $91.17 \pm 2.37 \mathrm{ab}$ & $80.95 \pm 9.91 \mathrm{ab}$ & $35.71 \pm 1.46 \mathrm{ab}$ & $0.85 \pm 0.03 a$ \\
\hline \multirow{10}{*}{ Experiment II } & $\mathrm{C}-$ & $0.00 \pm 0.00 \mathrm{c}$ & $0.00 \pm 0.00 \mathrm{c}$ & $0.00 \pm 0.00 \mathrm{~b}$ & $0.00 \pm 0.00 \mathrm{~d}$ & $0.00 \pm 0.00 \mathrm{~b}$ \\
\hline & V.d. & $90.48 \pm 6.15 a b$ & $68.49 \pm 5.43 \mathrm{a}$ & $47.62 \pm 9.91 \mathrm{a}$ & $26.76 \pm 2.95 \mathrm{a}$ & $0.53 \pm 0.05 a$ \\
\hline & V.d.+MTR17a & $71.43 \pm 15.31 \mathrm{ab}$ & $50.21 \pm 7.88 \mathrm{ab}$ & $33.33 \pm 10.29 a b$ & $15.05 \pm 2.81 \mathrm{bc}$ & $0.20 \pm 0.09 a b$ \\
\hline & V.d.+MTR17d & $95.24 \pm 4.76 \mathrm{a}$ & $70.22 \pm 3.93 \mathrm{a}$ & $23.81 \pm 14.02 \mathrm{ab}$ & $23.04 \pm 2.20 \mathrm{ab}$ & $0.40 \pm 0.20 \mathrm{ab}$ \\
\hline & V.d.+MTR17f & $85.71 \pm 9.91 \mathrm{ab}$ & $64.79 \pm 6.12 \mathrm{a}$ & $33.33 \pm 14.51 \mathrm{ab}$ & $22.95 \pm 2.67 \mathrm{ab}$ & $0.38 \pm 0.17 a b$ \\
\hline & V.d.+MTR17g & $80.95 \pm 6.73 a b$ & $58.36 \pm 6.85 a b$ & $38.10 \pm 11.34 \mathrm{ab}$ & $16.81 \pm 2.84 \mathrm{abc}$ & $0.27 \pm 0.12 a b$ \\
\hline & V.d.+MTR17h & $52.38 \pm 12.30 \mathrm{~b}$ & $35.15 \pm 7.58 b$ & $4.76 \pm 4.76 \mathrm{~b}$ & $10.51 \pm 2.58 \mathrm{~cd}$ & $0.10 \pm 0.04 b$ \\
\hline & V.d.+MTR17b & $80.95 \pm 9.91 \mathrm{ab}$ & $57.05 \pm 6.52 a b$ & $19.05 \pm 6.73 a b$ & $14.85 \pm 2.03 b c$ & $0.40 \pm 0.18 a b$ \\
\hline & V.d.+MTR17c & $76.19 \pm 9.52 \mathrm{ab}$ & $49.66 \pm 7.35 a b$ & $23.81 \pm 6.15 a b$ & $11.73 \pm 2.35 \mathrm{c}$ & $0.13 \pm 0.06 a b$ \\
\hline & V.d.+TRIANUM-P & $52.38 \pm 6.74 \mathrm{~b}$ & $33.45 \pm 7.44 \mathrm{~b}$ & $4.76 \pm 4.76 b$ & $7.88 \pm 1.94 \mathrm{~cd}$ & $0.20 \pm 0.09 a b$ \\
\hline
\end{tabular}


${ }^{a}$ Disease parameters were evaluated periodically on the basis of external symptoms during a period of 24 days (in Experiment I) and 30 days (in Experiment II) after root 
Table 4. Number of genes related to Virulence, Disease and Defense features of the three new bacterial species identified in this study. The genome analysis and the annotation was performed using the RAST genome annotation software.

\begin{tabular}{|c|c|c|c|c|}
\hline Virulence, Disease and Defense & Arthrobacter sp. CMR16 & Pseudomonas sp. CrR25 & Pseudomonas sp. CMR27 & Pseudomonas sp. CMR25 \\
\hline Resistance to antibiotics and toxic compounds & 19 & 56 & 42 & 45 \\
\hline Mercury resistance operon & 1 & 0 & 0 & 0 \\
\hline Copper homeostasis & 6 & 25 & 18 & 18 \\
\hline Cobalt-zinc-cadmium resistance & 4 & 12 & 17 & 16 \\
\hline Resistance to fluoroquinolones & 2 & 5 & 2 & 5 \\
\hline Copper homeostasis: copper tolerance & 2 & 2 & 2 & 2 \\
\hline Beta-lactamase & 1 & 0 & 2 & 1 \\
\hline Mercuric reductase & 3 & 3 & 0 & 0 \\
\hline Multidrug Resistance Efflux Pumps & 0 & 7 & 0 & 0 \\
\hline Resistance to chromium compounds & 0 & 1 & 1 & 3 \\
\hline Invasion and intracellular resistance & 19 & 21 & 14 & 17 \\
\hline $\begin{array}{l}\text { Mycobacterium virulence operon involved in } \\
\text { protein synthesis (SSU ribosomal proteins) } \\
\text { Mycobacterium virulence operon involved in }\end{array}$ & 6 & 9 & 6 & 7 \\
\hline $\begin{array}{l}\text { DNA transcription } \\
\text { Mycobacterium virulence operon possibly }\end{array}$ & 3 & 6 & 2 & 4 \\
\hline $\begin{array}{l}\text { involved in quinolinate biosynthesis } \\
\text { Listeria surface proteins: Internalin-like }\end{array}$ & 3 & 3 & 3 & 3 \\
\hline $\begin{array}{l}\text { proteins } \\
\text { Mycobacterium virulence operon involved in }\end{array}$ & 4 & 0 & 0 & 0 \\
\hline protein synthesis (LSU ribosomal proteins) & 3 & 3 & 3 & 3 \\
\hline $\begin{array}{l}\text { Bacteriocins, ribosomally synthesized } \\
\text { antibacterial peptides }\end{array}$ & 0 & 2 & 2 & 2 \\
\hline Tolerance to colicin E2 & 0 & 2 & 2 & 2 \\
\hline Membrane Transport & 14 & 77 & 86 & 83 \\
\hline $\begin{array}{l}\text { Protein secretion system, Type II (Widespread } \\
\text { colonization island) }\end{array}$ & 11 & 14 & 10 & 10 \\
\hline
\end{tabular}


Protein secretion system, Type II (General Secretion Pathway)

Protein secretion system, Type V (Two partner

secretion pathway - TPS)

Protein secretion system, Type I

Protein secretion system, Type III

Protein secretion system, Type VI

Protein and nucleoprotein secretion system,

Type IV (Type IV pilus)

Protein and nucleoprotein secretion system,

Type IV ( Conjugative transfer)

Protein secretion system, Type VI

(Chaperone/Usher pathway, CU)

Twin-arginine translocation system

Protein secretion system, Type VIII

(Extracellular nucleation/precipitation pathway, ENP
15 
bioRxiv preprint doi: https://doi.org/10.1101/2020.07.29.226860; this version posted July 29, 2020. The copyright holder for this preprint (which was not certified by peer review) is the author/funder. All rights reserved. No reuse allowed without permission.

Christakis et. al., Halophytic Endophytes in sustainable agriculture

995 